\title{
Metallic Structures: Effective Agents to Fight Pathogenic Microorganisms
}

\author{
Diana Pereira $^{1}$, Tiago Soares Carreira ${ }^{2}$, Nuno Alves ${ }^{2, *} \mathbb{C}$, Ângela Sousa ${ }^{1}\left(\mathbb{D}\right.$ and Joana F. A. Valente ${ }^{2, * \mathbb{C}}$ \\ 1 CICS-UBI-Health Sciences Research Centre, Universidade da Beira Interior, Avenida Infante D. Henrique, \\ 6200-506 Covilhã, Portugal; diana.carvalho.pereira1@gmail.com (D.P.); angela@fcsaude.ubi.pt (Â.S.) \\ 2 CDRsp-IPL-Centre for Rapid and Sustainable Product Development, Polytechnic of Leiria, Marinha Grande, \\ 2430-028 Leiria, Portugal; tiagosc112@gmail.com \\ * Correspondence: nuno.alves@ipleiria.pt (N.A.); joana.valente@ipleiria.pt (J.F.A.V.); \\ Tel.: +351-244-569-441 (N.A. \& J.F.A.V.)
}

check for

updates

Citation: Pereira, D.; Carreira, T.S.; Alves, N.; Sousa, Â.; Valente, J.F.A. Metallic Structures: Effective Agents to Fight Pathogenic Microorganisms. Int. J. Mol. Sci. 2022, 23, 1165. https://doi.org/10.3390/ijms23031165

Academic Editors:

Ángel Serrano-Aroca, Murtaza

M. Tambuwala and Martin Birkett

Received: 28 December 2021

Accepted: 19 January 2022

Published: 21 January 2022

Publisher's Note: MDPI stays neutral with regard to jurisdictional claims in published maps and institutional affiliations.

Copyright: (C) 2022 by the authors. Licensee MDPI, Basel, Switzerland. This article is an open access article distributed under the terms and conditions of the Creative Commons Attribution (CC BY) license (https:// creativecommons.org/licenses/by/ $4.0 /)$.

\begin{abstract}
The current worldwide pandemic caused by coronavirus disease 2019 (COVID-19) had alerted the population to the risk that small microorganisms can create for humankind's wellbeing and survival. All of us have been affected, directly or indirectly, by this situation, and scientists all over the world have been trying to find solutions to fight this virus by killing it or by stop/decrease its spread rate. Numerous kinds of microorganisms have been occasionally created panic in world history, and several solutions have been proposed to stop their spread. Among the most studied antimicrobial solutions, are metals (of different kinds and applied in different formats). In this regard, this review aims to present a recent and comprehensive demonstration of the state-of-the-art in the use of metals, as well as their mechanisms, to fight different pathogens, such as viruses, bacteria, and fungi.
\end{abstract}

Keywords: antimicrobial agents; bacteria; fungi; metals; virus

\section{Introduction}

Over the years, multidrug-resistant pathogenic microorganisms have emerged due to the overuse and misuse of antibiotics (and other drugs) against different types of infections, and also because of pathogens' innate ability to genetically acquire drug resistance [1]. Among the biggest enemies of antimicrobial drug treatments, is biofilm formation by microorganisms, since the extracellular polymeric substances from these biostructures work as an effective metabolic and physical barrier, developing antibiotic or antifungal resistance by making drug entrance difficult and consequently reducing effectiveness [2]. This poses a serious threat to public health as it becomes a challenge to treat the infections caused by these "superbugs" [3,4].

Most recently, the COVID-19 pandemic has emphasized how unprepared humanity is to fight threats associated with epidemic outbreaks of infectious diseases. Severe acute respiratory syndrome coronavirus 2 (SARS-CoV-2) is the latest in a long list of viral diseases that have emerged as severe threats to public health [5]. There have been made many attempts to develop medicines and vaccines to fight viruses; however, their ability for quick adaptation in their current host, and the ability to switch to a new host, are matters of great concern.

An example of a possible therapeutic target against the infection induced by SARS$\mathrm{CoV}-2$ can be the main SARS-CoV-2 protease, which plays an important role in the virus lifecycle, through the application of cannabinoid receptor type 2, which is highly expressed in immune cells, inhibiting inflammatory processes [6,7]. Concerning cannabinoid use, Raj et al. (2021) found that these molecules are important to inhibit viral replication of SARS-CoV-2 in two ways: by binding to the main protease and blocking translation, and 
by acting as agonists for the cannabinoid receptor, therefore reducing the levels of proinflammatory cytokines [8]. Hence, there is still an urgent need to develop novel potential antiviral agents [9].

In this regard, metals have been used for centuries due to their exceptional ability to work as antimicrobial agents for different applications, such as in healthcare, food, and agriculture, among others. Moreover, the application of these kinds of materials as biocidal agents had grown so much that the global metal biocides market is projected to reach USD 3.49 billion by 2021 with a compound annual growth rate of $4.8 \%$ from 2016 to 2021 (https:/ / www.marketsandmarkets.com/Market-Reports/metal-biocide-market-12 1653989.html, access on 4 November 2021).

To fight some of these pathogens, society has been using metals, such as mercury, silver $(\mathrm{Ag})$, gold $(\mathrm{Au})$, and iron $(\mathrm{Fe})$, and, more recently, other types of metals, such as titanium (Ti) and zinc ( $\mathrm{Zn})$, among others. Each of these has various properties, potencies, and spectra of activity, and could be used in different formats that can range from surfaces and coatings to nano- or microparticles without losing their ability to kill microorganisms.

The main mechanisms of action of metals could be triggered by metal reduction potential and through metal donor atom selectivity and/or speciation. Additionally, another possible classification for these mechanisms can be based on where the biocidal metal acts: either in the cell membrane or in the intracellular region (more detailed information will be provided in the following section) [10].

Regarding the above mentioned, this review intends to present the latest advances in the field of the use of metals as biocidal agents, focusing also on mechanisms behind this effect. The presented approaches will address different structures that can be applied, such as surfaces or coatings, as well as nano- or microparticles. Antimicrobial solutions will be also presented, where metals are synergistically combined with drugs or polymers to increase the potency of the biocidal effect.

\section{Mechanisms behind the Antimicrobial Effect}

In general, metals represent a considerable portion of the periodic table, and their properties can correlate with reactivity in living cells. They are required for the correct functioning of many enzymes and are involved in nearly all biological processes, providing structural stability for proteins, cell membranes, and DNA; they are co-factors for enzymes; and redox potential to facilitate electron transport and catalysis [11,12].

Even though they are essential for many biological functions, metals can also be toxic and lethal when in excess. Among many things, they can increase intracellular reactive oxygen species (ROS) via Fenton chemistry, inducing oxidative stress; disrupting membrane function and cell growth processes; and damage DNA and negatively influencing enzyme activities and protein function [11-13].

The toxicity of metals is achieved through multiple mechanisms of action, such as reduction potential-which interferes with the electron transfer process, preventing cells from acquiring electrons that are essential to cellular functions, and donor atom selectivitywhere a protein binds to the wrong metal cofactor and ends up with compromised folding or function [13].

Regarding the production of ROS, relevant mechanisms have been proposed through which this could be accomplished, such as the existence of other redox-active metals (such as $\mathrm{Fe}$, copper $(\mathrm{Cu})$, and nickel $(\mathrm{Ni})$ ), which can lead to Fenton chemistry, the destruction of Fe-sulfur (S) protein clusters, resulting in the release of additional Fe into the cytoplasm, which is Fenton-active and able to produce ROS in excess; and, last but not least, the oxidation of thiols within cells, which leads to the production of $S$ radicals, forming protein disulfides and depleting glutathione reserves, leaving protein targets susceptible to attack by metals or ROS [11].

Furthermore, some metals apply their toxicity outside the microorganism barrier, by simply binding to the membrane, while others can bind to ligands of low molecular mass that present functional groups, such as phosphate, amino acids, or peptides, and be 
co-transported into the cell. Once inside a cell, they can cause a loss of enzyme activity, protein dysfunction, genotoxicity, and interfere with the assimilation of nutrients, which leads to growth arrest via starvation. Additionally, some metals, such as Ag, can interfere with the electron transport chain by interfering with sodium ion $\left(\mathrm{Na}^{+}\right)$[11].

Despite the above-mentioned points, the different metabolisms of microorganisms in combination with the multiple processes evolved in terms of their growth inhibition/death, it is difficult to fully understand metal-derived toxicity. Nevertheless, electrostatic interactions, established between the metal ions (positively charged) and the components of the bacterial cell wall (negatively charged), are indicated as the main effect [14].

\section{Metallic Particles-Nano- and Microstructures}

\subsection{Nanoparticles}

Nanomaterials are reported to have dimensions between 1-100 nm. Due to their small size, nanoparticles (NPs) can be used for biosensing, drug delivery, bioimaging, catalysis, nanomanufacturing, lubrication, electronics, in the textile industry, and for water treatment. They can also cooperate with biomolecules inside cells or on the cell surface, carrying drugs or genetic materials, such as DNA, RNA, or small interfering RNA (siRNA), into target cells or tissues for gene expression $[15,16]$.

The use of NPs as antimicrobial agents could overcome mechanisms of bacterial resistance due to their microbicidal nature, which results from direct contact with the bacterial cell wall, without the need to penetrate the cell [16]. Therefore, there is less chance to develop antibacterial resistance to NPs when compared to antibiotics, allowing NPs the potential to be used for antimicrobial theragnostics in medicine [17]. Metal NPs (M-NPs) have been shown to have in vitro antimicrobial activity against a wide range of organisms, including Gram-positive and Gram-negative bacteria, mycobacteria, fungi, and viruses [15,17].

These kinds of NPs can be produced using two different methods: top-down and bottom-up. A top-down method is a destructive approach that starts from a larger molecule that is decomposed into smaller units, which are then converted into suitable NPs. The bottom-up approach is performed in reverse, with the NPs being formed from relatively simpler substances $[18,19]$. Table 1 describes different methods applied for M-NPs production. 
Table 1. Different methods for M-NPs synthesis.

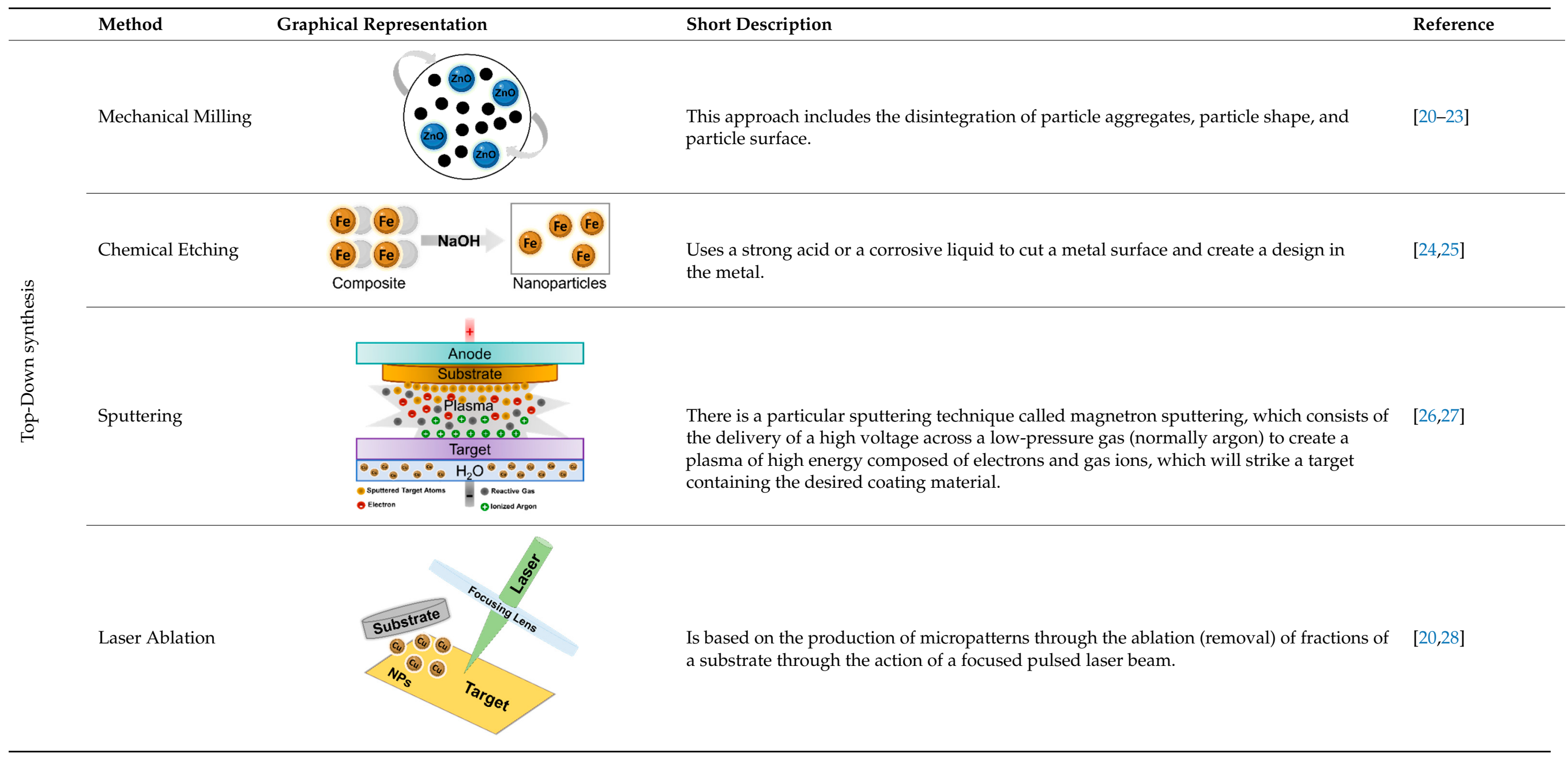


Table 1. Cont.

Method

Electro Explosion

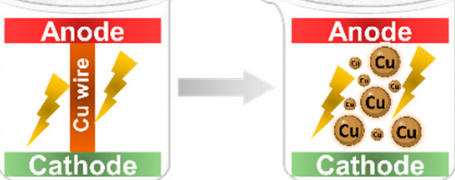

Single-step process in which a delicate wire of a conductive metal is exploded by an electric discharge that is caused by a high-power DC source. This electronic discharge creates a massive temperature that vaporizes the thin wire, turning it into gas atoms, which in their turn are chilled and, finally, the NPs are synthesized.
Bottom- Chemical

up Deposition

syn-

thesis
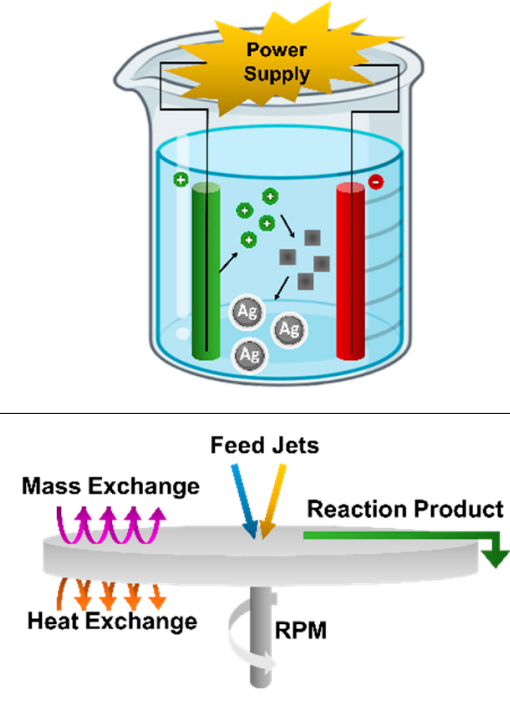

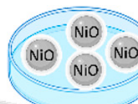

\section{$\mathbf{N i}$}

Sol-Gel

Spinning

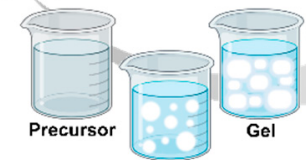

In particular, electrochemical deposition or electrochemical precipitation involves the passage of an electric current between an anode (sacrificial) and a cathode localized in an electrolyte. The anode is oxidized into metal ions and these are then reduced to metal by the cathode with the help of stabilizers.
A wet-chemical process, with sol being a colloidal solution of solids suspended in a liquid $[20,24,33-35]$ phase that serves as a metal precursor and is then dispersed into the gel, a host liquid

leading to the formation of a solid macromolecule submerged in the solvent. After, there is a separate phase where the gel is dried and dehydrated to recover the NPs. 
Table 1. Cont.

Method Graphical Representation

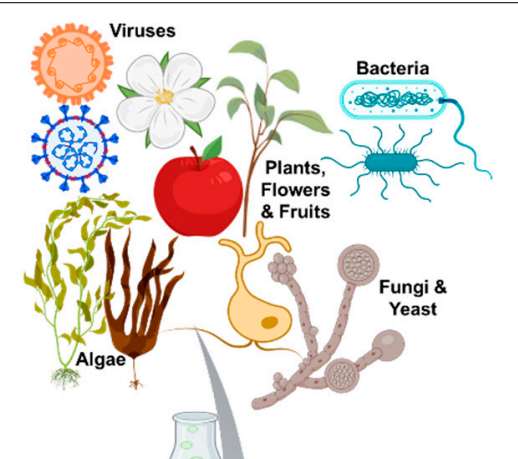

Biosynthesis

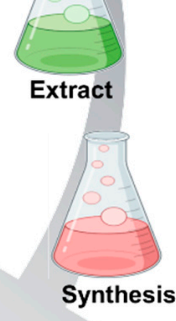

Au

Au Au
Metalsynthesis is bio-mediated by microbes or through biosynthesis. Biological synthesis of nanomaterials is the best alternative being cost-effective, environmentally friendly, advantageous and does not comprise any input of toxic chemicals. Between the

candidates to biosynthesize M-NPs are bacteria, fungi and yeast; algae; plants, flowers and fruits; and viruses. 
These metallic nanostructures have several applications in numerous fields, such as in diagnostics, drug delivery, antimicrobial activity, and the treatment of several diseases [39]. M-NPs are widely recognized to have antimicrobial properties and are already widespread as antimicrobial agents with several products for antimicrobial purposes having been approved by regulatory agencies and commercialized. Some of these NPs have been used in combination with certain antibiotics to help overcome resistant bacteria, enhancing the antibiotic effect [40]. In addition, nanomaterials can be moulded to incorporate conventional antiviral properties with modifications that are exclusive to nanosystems, such as small and controllable sizes that can represent a solution for the treatment of viral infections [41,42].

The main components of the bacterial cell wall are peptidoglycans linked to teichoic acid, glycolipids, and phospholipids, which provide a negative charge to the cell wall. The interaction between the positively charged metal ions and the cell wall is enabled by this negative charge, which leads to a loss of membrane integrity. This damaged membrane can cause a leakage of cytoplasmatic content, such as minerals and genetic material, with a consequent rupturing of the cell, leading to cell death. Furthermore, if M-NPs enter the bacterial cell, they poison the microbial cells by generating ROS (which mediate cellular damage) or through metal-catalyzed oxidation reaction that could lead to disfunction of proteins or DNA and interfere with the assimilation of nutrients by the cell [43].

Nguyen and co-workers studied the antimicrobial mechanisms of magnesium oxide MgO-NPs, and SEM images of Gram-negative bacteria, such as Escherichia coli (E. coli), showed membrane damage when they were seeded with high doses of MgO-NPs. These Gram-negative bacteria present a thin layer of peptidoglycan between the phospholipid layers so the MgO-NPs can easily pass through the cell wall and bind to the membrane, causing shape distortion and cell death. On the contrary, Gram-positive bacteria present a thick surface layer made of peptidoglycan that retains the MgO-NPs. This characteristic can inhibit cell growth and prevent cell adhesion to surfaces [44]. Shankar and Rhim also reported a difference between Gram-positive and Gram-negative bacteria, regarding antimicrobial activity when Ag-NPs were used. Similarly, Ag-NPs also experience more difficulty in penetrating the peptidoglycan layer (20-80 nm) in Gram-positive bacteria, in contrast to what happens to the outer membrane of Gram-negative bacteria $(7-8 \mathrm{~nm})$ [45].

In particular, with Ag-NPs, it has been proposed that the release of positively charged silver ions $\left(\mathrm{Ag}^{+}\right)$may interact with the negatively charged proteins or nucleic acids, damaging the structure and deforming the bacterial cell walls and membranes. This phenomenon will disrupt metabolic processes, leading to eventual cell death. It has also been suggested that ROS derived from the NP surface causes membrane damage by increasing membrane permeability, which will lead to cell death [45-47]. Chatterjee and collaborators (2015) also reported that, after treatment with AG-NPs, the cellular DNA of E. coli and Staphylococcus aureus (S. aureus) showed condensation, and E. coli cells were more susceptible to the treatment compared to $S$. aureus, probably due to the difference in structure, which has been previously described in the literature [46].

Iron NPs could be applied per se as antimicrobial agents or can act as hyperthermia agents to treat bacterial infections (this kind of microorganism shows a higher temperature susceptibility than healthy human host cells) [48]. When placed under an alternating magnetic field with a high frequency and amplitude, these particles will absorb electromagnetic radiation and subsequently convert the magnetic energy into localized heat, leading to bacteria death [49]. The study by Kim et al. (2013) can be cited as a good example of an effective application of Fe-magnetic NPs combined with hyperthermia to provide antimicrobial efficacy in a mouse infection model caused by S. aureus [50].

Similar to what happens with bacteria, antifungal mechanisms provided by M-NPs can be associated with a disturbance of fungal cell membrane integrity, and with the generation of ROS, which enhances the membrane disintegration process [51]. With metal toxicity comes a depletion of glutathione and a loss of antioxidant response to oxidative stress [52,53]. Table 2 provides different examples of experiments regarding the antimicrobial action of M-NPs against several pathogens. 
Table 2. Summary of some experiments regarding the antimicrobial action of M-NPs against different pathogens.

\begin{tabular}{|c|c|c|c|c|c|}
\hline NPs & Microbes & Synthesis Method & Applications & Main Results & Reference \\
\hline \multirow[t]{3}{*}{$\mathrm{Zn}$} & $\begin{array}{l}\text { Gram-positive bacteria: } \\
\text { Streptococcus pneumonia, } \\
\text { S. aureus, and Bacillus } \\
\text { subtilis } \\
\text { Gram-negative bacteria: } \\
\text { Salmonella typhimurium, } \\
\text { Pseudomonas aeruginosa, } \\
\text { and E. coli O157:H7 } \\
\text { Fungi and Yeast: Candida } \\
\text { albicans, Candida glabrata, } \\
\text { Candida guilliermondii, } \\
\text { and Candida krusei }\end{array}$ & $\begin{array}{l}\text { Green synthesis by } \\
\text { Ziziphora clinopodioides } \\
\text { extract }\end{array}$ & $\begin{array}{l}\text { Cutaneous wound } \\
\text { healing; } \\
\text { Medical, biomedical and } \\
\text { pharmaceutical research }\end{array}$ & $\begin{array}{l}\text { Antibacterial, antifungal } \\
\text { and antioxidant effects, } \\
\text { without any cytotoxicity. } \\
\text { Wound healing with } \\
\text { increased levels of } \\
\text { wound contracture, } \\
\text { vessel, hydroxyl proline, } \\
\text { hexosamine, hexuronic } \\
\text { acid and fibro- } \\
\text { cytes/fibroblast rate. } \\
\text { Growth inhibition } \\
\text { concentrations were } \\
1 \text { mg/mL for } \\
\text { C. guilliermondii and } \\
\text { C. krusei, } 2 \text { mg/mL for } \\
\text { P. aeruginosa, S. aureus, } \\
\text { S. pneumonia, B. subtilis, } \\
\text { C. albicans and } \\
\text { C. glabrata, and } \\
4 \text { mg/mL for E. coli and } \\
\text { S. typhimurium. }\end{array}$ & [54] \\
\hline & $\begin{array}{l}\text { Gram-positive bacteria: } \\
\text { S.aureus, Mycobacterium } \\
\text { tuberculosis }\end{array}$ & $\begin{array}{l}\text { Extracellular by } \\
\text { Pseudomonas hibiscicola }\end{array}$ & $\begin{array}{l}\text { Drug-resistant strains } \\
\text { hospital-acquired } \\
\text { infections, treatment and } \\
\text { prevention therapy. }\end{array}$ & $\begin{array}{l}\text { Antibacterial potential. } \\
\text { Synergism with } \\
\text { gentamicin against } \\
\text { MRSA. } \\
\text { The minimum inhibitory } \\
\text { concentrations (MIC) } \\
\text { were } 2.5 \mathrm{mg} / \mathrm{mL} \text { for } S \text {. } \\
\text { aureus and } 1.25 \mathrm{mg} / \mathrm{mL} \\
\text { for } M \text {. tuberculosis. }\end{array}$ & [55] \\
\hline & Virus: Hepatitis A & $\begin{array}{l}\text { Hesperidin mediated } \\
\text { synthesis }\end{array}$ & Drug development & $\begin{array}{l}\text { Hesperidin-mediated } \\
\text { ZnO NPs exhibit better } \\
\text { antiviral activity than } \\
\text { hesperidin alone. } \\
\text { Hesperidin and } \mathrm{ZnO} \\
\text { NPs showed antiviral } \\
\text { activity against } \\
\text { Hepatitis A virus (HAV) } \\
\text { with } \mathrm{EC}_{50 \mathrm{~s}} \text { equal to } 72.4 \\
\text { and } 176.3 \mu \mathrm{g} / \mathrm{mL} \text {. }\end{array}$ & {$[56]$} \\
\hline $\mathrm{ZnO}$ & $\begin{array}{l}\text { Fungi and Yeast: } C \text {. } \\
\text { Albicans }\end{array}$ & $\begin{array}{l}\text { Green synthesis by } \\
\text { Prosopis farcta aqueous } \\
\text { extract }\end{array}$ & Industrial and medicinal & $\begin{array}{l}\text { Antifungal effects and } \\
\text { reduction of cell viability } \\
\text { in cancer cells by } \\
\text { increasing the ZnO-NPs } \\
\text { concentration. } \\
\text { The antifungal activity } \\
\text { of ZnO-NPs against C. } \\
\text { Albicans has shown that } \\
\text { the MIC and minimum } \\
\text { fungicidal concentration } \\
\text { (MFC) were } 128 \text { and } \\
256 \mu \mathrm{g} / \mathrm{mL} \text {, respectively. }\end{array}$ & [57] \\
\hline
\end{tabular}


Table 2. Cont.

\begin{tabular}{|c|c|c|c|c|c|}
\hline NPs & Microbes & Synthesis Method & Applications & Main Results & Reference \\
\hline & Virus: H1N1 Influenza & - & Biomedical & $\begin{array}{l}\text { Antiviral activity and } \\
\text { reduction of cell } \\
\text { cytotoxicity in } \\
\text { MDCK-SIAT1 cells with } \\
\text { a maximum noncyto- } \\
\text { toxic concentration of } \\
75 \mu \mathrm{g} / \mathrm{mL} \text {. }\end{array}$ & [58] \\
\hline \multirow[t]{3}{*}{$\mathrm{Fe}$} & $\begin{array}{l}\text { Gram-positive bacteria: } \\
\text { S. aureus } \\
\text { Gram-negative bacteria: } \\
\text { P. aeruginosa, and E. coli }\end{array}$ & Ferric iron reduction & Biomedical & $\begin{array}{l}\text { Strong antibacterial } \\
\text { effect considering the } \\
\text { MIC values of } 1.96, \\
31.25 \text {, and } 15.75 \mu \mathrm{g} / \mathrm{mL} \text {, } \\
\text { and } \mathrm{MBC} \text { values of } 1.96 \text {, } \\
31.25 \text {, and } 31.25 \mu \mathrm{g} / \mathrm{mL} \\
\text { for E. coli, P. aeruginosa } \\
\text { and } S \text {. aureus, } \\
\text { respectively. }\end{array}$ & [59] \\
\hline & $\begin{array}{l}\text { Vírus: Chikungunya } \\
\text { virus (CHIKV) }\end{array}$ & $\begin{array}{l}\text { Green synthesis from } \\
\text { impregnation into raw } \\
\text { Citrus limetta peels }\end{array}$ & Therapeutic & $\begin{array}{l}\text { Antiviral activities of } \\
\text { Fe-NPs at concentrations } \\
\text { of } 0.05 \mathrm{mg} / \mathrm{mL}, 0.1 \\
\mathrm{mg} / \mathrm{mL} \text {, and } 0.2 \mathrm{mg} / \mathrm{mL} \\
\text { and an } \mathrm{IC}_{50} \text { value of } \\
15.52 \mu \mathrm{g} / \mathrm{mL} \text {. }\end{array}$ & {$[60]$} \\
\hline & $\begin{array}{l}\text { Fungi: Fusarium } \\
\text { oxysporum, Fusarium } \\
\text { tricinctum, Fusarium } \\
\text { maniliforme, Rhizoctonia } \\
\text { solani, and Phythium sp. }\end{array}$ & $\begin{array}{l}\text { Phyco-synthesis with } \\
\text { aqueous extract of the } \\
\text { green microalga } \\
\text { Chlorella K01 }\end{array}$ & Biomedical & $\begin{array}{l}\text { Iron oxide nanoparticles } \\
\text { at } 1 \mathrm{mg} / \mathrm{L} \text { inhibited the } \\
\text { radial growth of all } \\
\text { fungal pathogens tested. }\end{array}$ & [61] \\
\hline \multirow[t]{2}{*}{$\mathrm{Fe}_{3} \mathrm{O}_{4}$} & $\begin{array}{l}\text { Fungi: Trichothecium } \\
\text { roseum, Cladosporium } \\
\text { herbarum, Penicillium } \\
\text { chrysogenum, Alternaria } \\
\text { alternata and } \\
\text { Aspergillus niger }\end{array}$ & Green synthesis & Biomedical & $\begin{array}{l}\text { Antibacterial activity } \\
\text { with MIC values of } \\
0.063 \mathrm{mg} / \mathrm{mL} \text { for } \\
\text { Trichothecium roseum and } \\
\text { Cladosporium herbarum, } \\
0.032 \mathrm{mg} / \mathrm{mL} \text { for } \\
\text { Alternaria alternata and } \\
0.016 \mathrm{mg} / \mathrm{mL} \text { for } \\
\text { Penicillium chrysogenum. } \\
\text { and A.niger. }\end{array}$ & {$[62]$} \\
\hline & Vírus: H1N1 influenza & Chemical & Biomedical & $\begin{array}{l}\text { A major decrease in viral } \\
\text { RNA concentration with } \\
\text { the administration of } \\
7.5 \mathrm{pg} / \mathrm{mL} \text { of iron } \\
\text { oxide NPs. }\end{array}$ & [39] \\
\hline
\end{tabular}


Table 2. Cont.

\begin{tabular}{|c|c|c|c|c|c|}
\hline NPs & Microbes & Synthesis Method & Applications & Main Results & Reference \\
\hline $\mathrm{Ti}$ & $\begin{array}{l}\text { Gram-positive bacteria: } \\
\text { S. pneumonia, S. aureus, } \\
\text { and B. subtilis } \\
\text { Gram-negative bacteria: } \\
\text { S. typhimurium, } \\
\text { P. aeruginosa, and E. coli } \\
\text { Fungi and Yeast: } \\
\text { C. albicans, C. glabrata, } \\
\text { C. guilliermondii, and } \\
\text { C. krusei }\end{array}$ & $\begin{array}{l}\text { Green synthesis by } \\
\text { Ziziphora clinopodioides } \\
\text { extract }\end{array}$ & $\begin{array}{l}\text { Cutaneous wound } \\
\text { healing; } \\
\text { medical, biomedical and } \\
\text { pharmaceutical research }\end{array}$ & $\begin{array}{l}\text { Higher antibacterial and } \\
\text { antifungal effects than } \\
\text { all standard antibiotics } \\
\text { and antioxidant effects. } \\
\text { The MIC values were } \\
4 \mathrm{mg} / \mathrm{mL} \text { for } \\
\text { S. typhimurium, E. coli, } \\
\text { P. aeruginosa, S. aureus } \\
\text { and C. albicans and } \\
2 \mathrm{mg} / \mathrm{mL} \text { for } \\
\text { S. pneumonia, B. subtilis, } \\
\text { C. glabrata, } \\
\text { C. guilliermondii, and } \\
\text { C. krusei. } \\
\text { The MBC/MFC the } \\
\text { values were } 8 \mathrm{mg} / \mathrm{mL} \\
\text { for S. typhimurium and } \\
\text { E. coli, } 4 \text { mg/mL for } \\
\text { P. aeruginosa, S. aureus, } \\
\text { S. pneumonia, C. albicans, } \\
\text { C. glabrata and } \\
\text { C. guilliermondii and } \\
2 \text { mg/mL for B. subtilis } \\
\text { and C. krusei. }\end{array}$ & {$[63]$} \\
\hline $\mathrm{TiO}_{2}$ & $\begin{array}{l}\text { Gram-negative bacteria: } \\
\text { P. aeruginosa }\end{array}$ & $\begin{array}{l}\text { Green synthesis with the } \\
\text { extract of Trichoderma } \\
\text { citrinoviridae as a } \\
\text { reducing agent }\end{array}$ & $\begin{array}{l}\text { Food, health, } \\
\text { and medicine }\end{array}$ & $\begin{array}{l}\text { Inhibit the growth of } \\
\text { extremely drug-resistant } \\
\text { bacteria at } 100 \mu \mathrm{g} / \mathrm{mL} \\
\text { and also showed } \\
\text { antioxidant potential at } \\
\text { this concentration. }\end{array}$ & {$[64]$} \\
\hline $\mathrm{MgO}$ & $\begin{array}{l}\text { Gram-negative bacteria: } \\
\text { E. coli and P. aeruginosa } \\
\text { Gram-positive bacteria: } \\
\text { Staphylococcus epidermis, } \\
\text { S. aureus, } \\
\text { Methicillin-resistant S. } \\
\text { aureus (MRSA) } \\
\text { Fungi and Yeast: } \\
\text { C. albicans, C. glabrata }\end{array}$ & - & $\begin{array}{l}\text { Engineering } \\
\text { infection-free medical } \\
\text { devices and implants }\end{array}$ & $\begin{array}{l}\text { Bactericidal/fungicidal } \\
\text { effects. } \\
\text { MIC values of } \\
0.5 \mathrm{mg} / \mathrm{mL} \text { for } S \text {. } \\
\text { epidermis, } 0.7 \mathrm{mg} / \mathrm{mL} \text { for } \\
\text { S. aureus, } 1.0 \mathrm{mg} / \mathrm{mL} \text { for } \\
\text { E. coli, P. aeruginosa, } \\
\text { MRSA and C. glabrata, } \\
\text { and } 1.2 \mathrm{mg} / \mathrm{mL} \text { for } \\
\text { C. albicans. Moreover, } \\
\text { the minimum lethal } \\
\text { concentration (MLC) } \\
\text { values were } 0.7 \mathrm{mg} / \mathrm{mL} \\
\text { for } S . \text { epidermis and S. } \\
\text { aureus, } 1.0 \mathrm{mg} / \mathrm{mL} \mathrm{for} \\
\text { E. coli and C. glabrata, } \\
1.2 \mathrm{mg} / \mathrm{mL} \text { for } \\
\text { P. aeruginosa and } \\
\text { C. albicans, and } \\
1.4 \mathrm{mg} / \mathrm{mL} \text { for MRSA. }\end{array}$ & {$[44]$} \\
\hline
\end{tabular}


Table 2. Cont.

\begin{tabular}{|c|c|c|c|c|c|}
\hline NPs & Microbes & Synthesis Method & Applications & Main Results & Reference \\
\hline & $\begin{array}{l}\text { Gram-positive bacteria: } \\
\text { Streptococcus mutans and } \\
\text { Streptococcus sobrinus }\end{array}$ & - & Biomedical and dental & $\begin{array}{l}\text { Antibacterial activity } \\
\text { and antibiofilm } \\
\text { properties. The MIC and } \\
\text { MBC values were } \\
\text { determined at } \\
500 \mu \mathrm{g} / \mathrm{mL} \text { and } \\
1000 \mu \mathrm{g} / \mathrm{mL} \text {, } \\
\text { respectively, for both } \\
\text { S. mutans and S. sobrinus. }\end{array}$ & [65] \\
\hline & $\begin{array}{l}\text { Gram-negative bacteria: } \\
\text { E. coli, P.aeruginosa and } \\
\text { Aeromonas baumannii } \\
\text { Gram-positive bacteria: } \\
\text { S. pneumoniae and MRSA } \\
\text { Fungi and Yeast: } \\
\text { Fusarium solani, A. niger } \\
\text { and Aspergillus fumigatus }\end{array}$ & $\begin{array}{l}\text { Green synthesis with } \\
\text { marine brown algae } \\
\text { Sargassum wighitii as the } \\
\text { reducing and capping } \\
\text { agent }\end{array}$ & Biological & $\begin{array}{l}\text { Potent antimicrobial } \\
\text { activities against both } \\
\text { human pathogenic } \\
\text { bacterial and } \\
\text { fungal strains. } \\
\text { MIC for MRSA and } \\
\text { P. aeruoginosa was } \\
256 \mu \mathrm{g} / \mathrm{mL} \text { and the } \\
\mathrm{MBC} \text { was observed at } \\
256 \text { and } 1024 \mu \mathrm{g} / \mathrm{mL} \text { of } \\
\text { MgONPs for each } \\
\text { bacteria. } \\
\text { Antifungal experiments } \\
\text { (using } 10-30 \mu \mathrm{g} / \mathrm{mL} \text { of } \\
\text { MgONPs) showed } \\
\text { potent antifungal } \\
\text { activity when compared } \\
\text { to a positive control } \\
\text { (Fluconozole). } \\
\text { Also presented cytotoxic } \\
\text { activity against lung } \\
\text { cancer cell lines in a } \\
\text { dose-dependent manner. }\end{array}$ & [66] \\
\hline & $\begin{array}{l}\text { Virus: } \\
\text { Foot-and-mouth disease }\end{array}$ & - & $\begin{array}{l}\text { Therapeutic antiviral } \\
\text { agent in } \\
\text { foot-and-mouth disease }\end{array}$ & $\begin{array}{l}\text { Virucidal and antiviral } \\
\text { activities in the early } \\
\text { steps of the replication } \\
\text { cycle before virus entry } \\
\text { into the cell. } \\
\text { It was observed that } \\
\text { concentrations higher } \\
\text { than } 50 \mu \mathrm{g} / \mathrm{mL} \\
\text { inactivate the viruses. }\end{array}$ & [67] \\
\hline $\mathrm{Cu}$ & $\begin{array}{l}\text { Gram-negative bacteria: } \\
\text { E. coli and P.aeruginosa } \\
\text { Gram-positive bacteria: } \\
\text { S. aureus and B. subtilis } \\
\text { Fungi and Yeast: } \\
\text { C. albicans }\end{array}$ & $\begin{array}{l}\text { Biosynthesis using } \\
\text { aqueous Tilia extract }\end{array}$ & $\begin{array}{l}\text { Promising in electronic } \\
\text { devices: } \\
\text { Human cancer therapy }\end{array}$ & $\begin{array}{l}\text { Cytotoxicity against } \\
\text { human colon cancer, } \\
\text { human hepatic cancer } \\
\text { and human breast } \\
\text { cancer cells. } \\
\text { Relatively high activity } \\
\text { against pathogenic } \\
\text { bacteria with } \\
\text { concentrations ranging } \\
\text { from } 25 \text { to } 200 \mu \mathrm{g} / \mathrm{mL} \text {. }\end{array}$ & [68] \\
\hline
\end{tabular}


Table 2. Cont.

\begin{tabular}{|c|c|c|c|c|c|}
\hline NPs & Microbes & Synthesis Method & Applications & Main Results & Reference \\
\hline & $\begin{array}{l}\text { Gram-negative bacteria: } \\
\text { E. coli, Vibrio harveyi and } \\
\text { Vibrio parahemolyticus } \\
\text { Gram-positive bacteria: } \\
\text { B. subtilis and S. aureus } \\
\text { Fungi and Yeast: } R \text {. } \\
\text { solani and } \\
\text { Sclerotium oryzae }\end{array}$ & $\begin{array}{l}\text { Green synthesis using } \\
\text { Manilkara zapota leaf } \\
\text { extract }\end{array}$ & $\begin{array}{l}\text { Antiproliferative, } \\
\text { antimicrobial and } \\
\text { photocatalytic agent }\end{array}$ & $\begin{array}{l}\text { Antiproliferative effect } \\
\text { in breast cancer cell line. } \\
\text { Fungicidal activity for } R \text {. } \\
\text { solani and } S \text {. oryzae at } \\
\text { concentrations of } 50 \\
\mu \mathrm{g} / \mathrm{mL}, 100 \mu \mathrm{g} / \mathrm{mL} \text { and } \\
200 \mu \mathrm{g} / \mathrm{mL} \text {. As for } \\
\text { antibacterial activity B. } \\
\text { subtilis, } V \text {. } \\
\text { parahaemolyticus, } V \text {. } \\
\text { harveyi, S. aureus and } E \text {. } \\
\text { coli presented inhibition } \\
\text { at } 5 \mu \mathrm{g} / \mathrm{mL} \\
\text { concentration of } \\
\text { Cu-NPs. }\end{array}$ & [69] \\
\hline \multirow[t]{2}{*}{$\mathrm{CuO}$} & $\begin{array}{l}\text { Gram-positive bacteria: } \\
\text { S. mutans, Lactobacillus } \\
\text { casei, and Lactobacillus } \\
\text { acidophilus } \\
\text { Fungi and Yeast: C. } \\
\text { albicans, C. krusei, and C. } \\
\text { glabrata }\end{array}$ & - & Dental & $\begin{array}{l}\text { High antimicrobial effect } \\
\text { against dental caries } \\
\text { bacterial agents with } \\
\mathrm{MIC}_{50} \text { values of } \\
\text { CuO-NPs determined at } \\
\text { the range of } 1-10 \mu \mathrm{g} / \mathrm{mL} \\
\text { for } S \text {. mutans, }<1 \mu \mathrm{g} / \mathrm{mL} \\
\text { for } \mathrm{L} \text {. acidophilus, } 10 \\
\mu \mathrm{g} / \mathrm{mL} \text { for } \mathrm{L} \text {. casei and } \\
1000 \mu \mathrm{g} / \mathrm{mL} \text { for } \mathrm{C} \text {. } \\
\text { albicans, C. krusei, and C. } \\
\text { glabrata. }\end{array}$ & {$[70]$} \\
\hline & $\begin{array}{l}\text { Virus: herpes simplex } \\
\text { type } 1\end{array}$ & - & $\begin{array}{l}\text { Treatment of oro-labial } \\
\text { or genital herpetic } \\
\text { lesions }\end{array}$ & $\begin{array}{l}\text { Significant antiviral } \\
\text { potency against HSV-1, } \\
\text { with the production of } \\
\text { ROS through free Cu } \\
\text { ions released from the } \\
\text { NPs, where the optimal } \\
\text { concentration for the } \\
\text { antiviral effect was } \\
\text { found to be } 100 \mu \mathrm{g} / \mathrm{mL} \text {. }\end{array}$ & [71] \\
\hline $\mathrm{Cu}_{2} \mathrm{O}$ & $\begin{array}{l}\text { Gram-negative bacteria: } \\
\text { P. aeruginosa } \\
\text { Gram-positive bacteria: } \\
\text { B. subtilis }\end{array}$ & $\begin{array}{l}\text { Fabricated in reverse } \\
\text { micellar templates by } \\
\text { using lipopeptidal } \\
\text { biosurfactant as a } \\
\text { stabilizing agent }\end{array}$ & $\begin{array}{l}\text { Biocompatible } \\
\text { bactericidal and } \\
\text { therapeutic }\end{array}$ & $\begin{array}{l}\text { Potent antimicrobial } \\
\text { activity through } \\
\text { significant ROS } \\
\text { generation. The MIC } \\
\text { value was found to be } \\
62.5 \mu \mathrm{g} / \mathrm{mL} \text { for } B \text {. } \\
\text { subtilis and P. aeruginosa } \\
\text { microorganisms. }\end{array}$ & {$[72]$} \\
\hline $\mathrm{Au}$ & $\begin{array}{l}\text { Gram-negative bacteria: } \\
\text { Klebsiella pneumoniae, S. } \\
\text { typhimurium, E. coli and } \\
\text { P. aeruginosa } \\
\text { Gram-positive bacteria: } \\
\text { Bacillus cereus, B. subtilis, } \\
\text { S. aureus and Corallium } \\
\text { rubrum } \\
\text { Fungi and Yeast: C. } \\
\text { albicans, C. glabrata and } \\
\text { Cryptococcus neoformans }\end{array}$ & $\begin{array}{l}\text { Green synthesis using } \\
\text { seed extract of mango } \\
\text { (Mangifera indica) }\end{array}$ & $\begin{array}{l}\text { Therapeutic agents in } \\
\text { the biomedical field }\end{array}$ & $\begin{array}{l}\text { Moderate antibacterial, } \\
\text { cytotoxic and } \\
\text { antioxidant activity. In } \\
\text { addition, it exhibited } \\
\text { potential cytotoxicity on } \\
\text { cancer cell lines. } \\
\text { The inhibition of } \\
\text { bacteria and fungi } \\
\text { corresponded to } \\
\text { concentrations of } \\
50 \mathrm{mg} / \mathrm{mL} \text { of Au-NPs. }\end{array}$ & [73] \\
\hline
\end{tabular}


Table 2. Cont.

\begin{tabular}{|c|c|c|c|c|c|}
\hline NPs & Microbes & Synthesis Method & Applications & Main Results & Reference \\
\hline & $\begin{array}{l}\text { Gram-negative bacteria: } \\
\text { E. coli and P. aeruginosa } \\
\text { Gram-positive bacteria: } \\
\text { B. subtilis and } \\
\text { Streptococcus } \\
\text { Fungi and Yeast: } \\
\text { Aspergillus and } \\
\text { Penicillium }\end{array}$ & $\begin{array}{l}\text { Microwave-assisted } \\
\text { method using the leaf } \\
\text { extract of Synedrella } \\
\text { nodiflora as reducing and } \\
\text { stabilizing agent }\end{array}$ & $\begin{array}{l}\text { Field of biomedicine } \\
\text { and catalysis }\end{array}$ & $\begin{array}{l}\text { Effective antimicrobial } \\
\text { activity, significant } \\
\text { antioxidant properties } \\
\text { and potent catalytic } \\
\text { activity. Regarding the } \\
\text { antioxidant potential, } \\
\text { Au-NPs presented an } \\
\mathrm{IC}_{50} \text { of } 55.40 \mu \mathrm{g} / \mathrm{mL} \text {. }\end{array}$ & [74] \\
\hline & Virus: Influenza A & $\begin{array}{l}\text { Porous Au-NPs were } \\
\text { prepared following the } \\
\text { surfactant-free emulsion } \\
\text { method }\end{array}$ & $\begin{array}{l}\text { M-NPs-based therapy to } \\
\text { treat viral infection; } \\
\text { Multiplatform for } \\
\text { detection of the virus. }\end{array}$ & $\begin{array}{l}\text { Inhibited viral } \\
\text { membrane fusion by } \\
\text { blocking the viral entry } \\
\text { process through } \\
\text { conformational } \\
\text { deformation of } \\
\text { hemagglutinin. The cell } \\
\text { viability decreased to } \\
\text { less than } 60 \% \text { after } \\
10 \mathrm{~min} \text { of exposure to } \\
0.2 \mathrm{mg} / \mathrm{mL} \text { of Au-NPs. }\end{array}$ & [75] \\
\hline & Virus: Herpes Simplex & $\begin{array}{l}\text { Gallic acid-induced } \\
\text { rapid reduction reaction. }\end{array}$ & Virus chemotherapy. & $\begin{array}{l}\text { Prevented viral } \\
\text { attachment and } \\
\text { penetration. } \\
\text { The antiviral efficiency } \\
\text { had a } \mathrm{EC}_{50} \text { value of } \\
\text { approximately } 32.3 \text { and } \\
38.6 \mu \mathrm{M} \text { for HSV-1 and } \\
\text { HSV-2, respectively. }\end{array}$ & [76] \\
\hline \multirow[t]{2}{*}{$\mathrm{Ag}$} & $\begin{array}{l}\text { Gram-positive bacteria: } \\
\text { S.aureus, P. aeruginosa }\end{array}$ & $\begin{array}{l}\text { Extracellular by } \\
\text { Pseudomonas hibiscicola }\end{array}$ & $\begin{array}{l}\text { Drug-resistant strains } \\
\text { hospital-acquired } \\
\text { infections, treatment and } \\
\text { prevention therapy. }\end{array}$ & $\begin{array}{l}\text { Profound synergistic } \\
\text { antimicrobial activity } \\
\text { against drug-resistant } \\
\text { strains of MRSA, } \\
\text { extended-spectrum } 8 \\
\text { lactamases producer } \\
\text { (ESBL), } \\
\text { vancomycin-resistant } \\
\text { Enterococci (VRE), and } \\
\text { multi-drug resistant } \\
\text { (MDR) P. aeruginosa with } \\
\text { MIC values of } \\
2.5 \mathrm{mg} / \mathrm{mL} \text {. }\end{array}$ & [55] \\
\hline & $\begin{array}{l}\text { Gram-negative bacteria: } \\
\text { E. coli and P. aeruginosa } \\
\text { Gram-positive bacteria: } \\
\text { B. subtilis and } \\
\text { Streptococcus sp. } \\
\text { Fungi and Yeast: } \\
\text { Aspergillus sp. and } \\
\text { Penicillium sp. }\end{array}$ & $\begin{array}{l}\text { Microwave-assisted } \\
\text { method using Leaf } \\
\text { extract of Synedrella } \\
\text { nodiflora as reducing and } \\
\text { stabilizing agent }\end{array}$ & $\begin{array}{l}\text { Field of biomedicine } \\
\text { and catalysis }\end{array}$ & $\begin{array}{l}\text { Effective antimicrobial } \\
\text { activities and significant } \\
\text { antioxidant properties. } \\
\text { Regarding the } \\
\text { antioxidant potential, } \\
\text { Ag-NPs presented an } \\
\mathrm{IC}_{50} \text { of } 54.30 \mu \mathrm{g} / \mathrm{mL}\end{array}$ & [74] \\
\hline
\end{tabular}


Table 2. Cont.

\begin{tabular}{|c|c|c|c|c|c|}
\hline NPs & Microbes & Synthesis Method & Applications & Main Results & Reference \\
\hline & $\begin{array}{l}\text { Gram-negative bacteria: } \\
\text { E. coli O157:H7 } \\
\text { Gram-positive bacteria: } \\
\text { Listeria monocytogenes }\end{array}$ & $\begin{array}{l}\text { Green synthesis with a } \\
\text { lyophilized extract from } \\
\text { grape and orange wastes }\end{array}$ & Biomedical & $\begin{array}{l}\text { Growth inhibition of } \\
\text { bacteria in a } \\
\text { dose-dependent manner, } \\
\text { with the concentration } \\
\text { for inhibition ranging } \\
\text { from } 20 \text { to } 100 \mu \mathrm{g} / \mathrm{mL} \text {. }\end{array}$ & [77] \\
\hline & $\begin{array}{l}\text { Gram-negative bacteria: } \\
\text { E. coli, P. aeruginosa and } \\
\text { Salmonella typhi } \\
\text { Gram-positive bacteria: } \\
\text { S. aureus and } \\
\text { Enterococcus faecalis } \\
\text { Fungi and Yeast: A. niger, } \\
\text { C. albicans, Penicillium } \\
\text { notatum, Trichoderma } \\
\text { viridiae and Mucor sp. }\end{array}$ & $\begin{array}{l}\text { Green synthesis using } \\
\text { the leaf extracts of the } \\
\text { medicinal plant } \\
\text { Tropaeolum majus }\end{array}$ & $\begin{array}{l}\text { Therapeutic drug for } \\
\text { microbial infectious } \\
\text { disease and other health } \\
\text { associated disorders }\end{array}$ & $\begin{array}{l}\text { Antibacterial, antifungal, } \\
\text { antioxidant and } \\
\text { anticancer properties. } \\
\text { MIC values were } \\
3 \mu \mathrm{g} / \mathrm{mL} \text { for } S \text {. typhi, } \\
\text { S. aureus, E. faecalis and } \\
\text { C. albicans; } 4 \mu \mathrm{g} / \mathrm{mL} \text { for } \\
\text { E. coli and } A . \text { niger; } \\
6 \mu \mathrm{g} / \mathrm{mL} \text { for } P \text {. } \\
\text { aeruginosa and } 8 \mu \mathrm{g} / \mathrm{mL} \\
\text { for P. notatum, T. viridiae } \\
\text { and Mucor sp. }\end{array}$ & [78] \\
\hline & $\begin{array}{l}\text { Fungi: Verticillium } \\
\text { dahliae }\end{array}$ & $\begin{array}{l}\text { Green synthesis of } \\
\text { Ag-NPs using Melia } \\
\text { azedarach leaf extract }\end{array}$ & $\begin{array}{l}\text { Horticultural } \\
\text { applications }\end{array}$ & $\begin{array}{l}\text { Antifungal activity } \\
\text { where an application of } \\
60 \text { ppm of Ag-NPs } \\
\text { inhibited mycelial } \\
\text { growth with significant } \\
\text { effects in vivo. }\end{array}$ & [79] \\
\hline & $\begin{array}{l}\text { Virus: Herpes Simplex } \\
\text { types } 1 \text { and } 2\end{array}$ & $\begin{array}{l}\text { Modification with tannic } \\
\text { acid }\end{array}$ & $\begin{array}{l}\text { Vaginal treatment of } \\
\text { genital infection }\end{array}$ & $\begin{array}{l}\text { Affected viral } \\
\text { attachment, blocked } \\
\text { penetration and } \\
\text { cell-to-cell transmission } \\
\text { with an administration } \\
\text { of } 5 \text { ppm of Ag-NPs } \\
\text { modified with } \\
\text { Tannic Acid. }\end{array}$ & [80] \\
\hline & $\begin{array}{l}\text { Virus: HAV-10, Herpes } \\
\text { Simplex-1 and Coxackie } \\
\text { B4 (CoxB4) }\end{array}$ & $\begin{array}{l}\text { Green synthesis by } \\
\text { aqueous and hexane } \\
\text { extracts of Lampranthus } \\
\text { coccineus and } \\
\text { Malephora lutea }\end{array}$ & $\begin{array}{l}\text { Therapeutic and } \\
\text { biomedical }\end{array}$ & $\begin{array}{l}\text { Antiviral activity by } \\
\text { interaction with herpes } \\
\text { simplex thymidine } \\
\text { kinase, HAV 3c } \\
\text { proteinase and } \\
\text { Coxsackievirus B4 } \\
\text { 3c protease. } \\
\text { The IC } 50 \text { of HAV-1, } \\
\text { HSV-1 and CoxB4 } \\
\text { viruses was } 11.71,36.36 \\
\text { and } 12.74 \mu \mathrm{g} / \mathrm{mL} \text {, } \\
\text { respectively, with } \\
\text { Lampranthus coccineus } \\
\text { hexane nano extract, and } \\
31.38 \text { and } 29.04 \mu \mathrm{gg} / \mathrm{mL} \\
\text { only for HAV-10 and } \\
\text { CoxB4 with } \\
\text { Malephora lutea hexane } \\
\text { nano extract. }\end{array}$ & [81] \\
\hline
\end{tabular}


Table 2. Cont.

\begin{tabular}{|c|c|c|c|c|c|}
\hline NPs & Microbes & Synthesis Method & Applications & Main Results & Reference \\
\hline & $\begin{array}{l}\text { Virus: Severe acute } \\
\text { respiratory syndrome } \\
\text { coronavirus } 2\end{array}$ & - & Therapeutic & $\begin{array}{l}\text { Potent inhibition of viral } \\
\text { entry step via disrupting } \\
\text { viral integrity with the } \\
\text { administration of } \\
\text { concentrations ranging } \\
\text { from 1-10 ppm of } \\
\text { Ag-NPs. }\end{array}$ & [82] \\
\hline & $\begin{array}{l}\text { Virus: Respiratory } \\
\text { syncytial virus (RSV) }\end{array}$ & - & Therapeutic & $\begin{array}{l}\text { Reduced viral } \\
\text { replication and } \\
\text { production of } \\
\text { pro-inflammatory } \\
\text { cytokines in epithelial } \\
\text { cell lines and mouse } \\
\text { lungs. } \\
\text { A reduction of RSV } \\
\text { replication was } \\
\text { observed in Hep-2 and } \\
\text { A549 epithelial cell lines, } \\
\text { with an effective dose of } \\
50 \mu \mathrm{mg} / \mathrm{mL} \text { Ag-NPs. } \\
\text { Also, mouse lung tissue } \\
\text { incubated with } 4 \text { mg/kg } \\
\text { Ag-NPs presented a } \\
\text { significant reduction in } \\
\text { RSV copy numbers. }\end{array}$ & [83] \\
\hline & $\begin{array}{l}\text { Virus: Human } \\
\text { immunodeficiency virus }\end{array}$ & - & Therapeutic & $\begin{array}{l}\text { Exertion of anti-viral } \\
\text { activity at an early stage } \\
\text { of viral replication and } \\
\text { inhibitor of viral entry. } \\
{\text { The } \mathrm{IC}_{50} \text { was calculated }}_{\text {at approximately }} \\
0.44 \mathrm{mg} / \mathrm{mL} \text { of Ag-NPs } \\
\text { and the } \mathrm{CC}_{50} \text { (cytotoxic } \\
\text { concentration) in HeLa } \\
\text { cells was determined to } \\
\text { be approximately } \\
3.9 \mathrm{mg} / \mathrm{mL} \text {. }\end{array}$ & [84] \\
\hline & $\begin{array}{l}\text { Virus: Human } \\
\text { Papilloma virus }\end{array}$ & $\begin{array}{l}\text { Green synthesis using } \\
\text { Saccharina japonica } \\
\text { extract }\end{array}$ & $\begin{array}{l}\text { Prevention and } \\
\text { treatment of } \\
\text { cervical tumors }\end{array}$ & $\begin{array}{l}\text { Cytotoxic effect in the } \\
\text { human cervical } \\
\text { carcinoma cells, where } \\
\text { concentrations between } \\
0.16 \text { and } 0.32 \mathrm{mg} / \mathrm{mL} \text { of } \\
\text { Ag-NPs could inhibit } \\
\text { HeLa cells growth. }\end{array}$ & [85] \\
\hline
\end{tabular}

Antiviral mechanisms of M-NPs can occur either inside or outside host cells, as can be seen in Figure 1. These mechanisms include a competition between NPs and the virus for host cell-binding sites, to prevent viral attachment, and blocking virus-host binding or penetration. This kind of mechanism could be observed in recent research work performed by Jeremiah and co-workers, where Ag-NPs effectively inhibited extracellular SARS-CoV-2 by protecting target cells from infection. Another mechanism consists of inactivating virus particles before cellular entry, interacting with the viral genome, or binding to the viral particles, which can also be considered as potential mechanisms of action [84]. Furthermore, the intracellular compartment of an infected cell is abundant in the virally encoded and host cellular factors required for viral replication and production 
of virions. Hence, another antiviral mechanism of action is the interaction of M-NPs with these replication factors $[9,86]$. Overall, different NPs present different antiviral mechanisms of action, for example Au-NPs (similarly to Ag-NPs) include the blocking of glycoprotein envelope (gp120) attachment to inhibit viral entry or replication (as can be seen in Figure 1); Cu-NPs can destroy the viral genome and disrupt the capsid, Zn-NPs interfere with viral DNA polymerase activity, resulting in viral replication inhibition, and iron $(\mathrm{Fe}) \mathrm{NPs}(\mathrm{Fe}-\mathrm{NPs})$ bind to the virus to inhibit its binding to cells $[9,87]$.

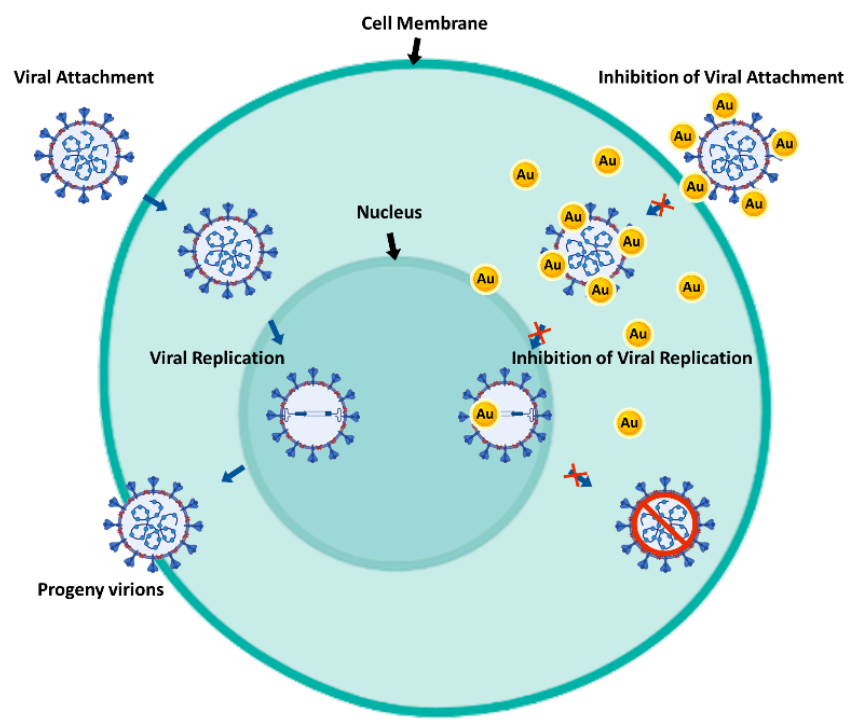

Figure 1. Representative mechanism of the antiviral properties of Au-NPs. On the left, a normal mechanism by which a virus infects a host cell (in this case, a eukaryotic cell) can be seen: firstly, viral attachment to the cell membrane occurs, followed by penetration into the cytoplasm; then the virus proceeds to use the cellular mechanisms to replicate its genetical material, generating virions to continue the infectious cycle. On the right, is shown a mechanism of inhibition by which Au-NPs can intervene, either by attaching themselves to the virus, blocking its attachment to the cell and consequent entry in the cell and ultimately interfering with the mechanisms of viral replication inside the cell (adapted from [88]).

Overall, there are many studies in the literature stating that the complete mechanism of action underlining the antimicrobial activity and efficacy of M-NPs is not fully clear or understood; however, among the parameters that influence the biocidal effects of metals are the size, shape, and metal ions involved [87]. With bacteriathis influence diverges between Gram-negative and Gram-positive cells, where M-NPs have more difficulty in passing through the thick layer of peptidoglycan in the Gram-positive cell wall, but, once inside the cell, the principles are the same. The antifungal mechanisms of M-NPs are similar to the antibacterial ones, which are the rupture of the cell membrane by oxidative stress and leakage of DNA and proteins. Regarding the antiviral mechanisms of M-NPs, they compete with the virus for cell-binding sites, therefore, inhibiting virus attachment to the cell, or preventing viral replication inside the cell.

\subsection{Microparticles}

Microparticles (MPs) are spherical particles that range in size from 0.1 to $1000 \mu \mathrm{m}$ and can be synthesized from natural and synthetic materials, such as polymers, glass, and ceramics. Similar to what happens with NPs, their small size gives them an advantage over larger particles (macroscale) and presents many desirable properties for a variety of different applications, such as drug delivery $[89,90]$.

In general, MPs are very similar to NPs in terms of their synthesis methods and applications, except for their size, which is bigger. Similar to NPs, MPs are commonly used to promote antimicrobial effects in different industries, and can be used as a drug delivery 
system due to their ability to protect from degradation bioactive drugs, proteins, and small molecules; they are also capable of controlling the release rate of encapsulated drugs over an extended period, up to months, and also, they are easily processed [89,91].

Some studies have been conducted regarding the use of MPs against different pathogens. For instance, Sophee and co-workers synthesized titanium oxide $\left(\mathrm{TiO}_{2}\right)$ and $\mathrm{ZnO} \mathrm{MPs}$ using the sol-gel method to prevent water-borne microbial infections. From the obtained results, it was possible to enhance the antibacterial activity against Gram-negative bacteria (E. coli and K. pneumoniae) and Gram-positive bacteria (Streptococcus pyogenes) [92]. More recently, Steckiewicz and coworkers studied spherical Ag-orthophosphate-MPs, produced by chemical precipitation, against Gram-positive bacteria (S. aureus) and fungi/yeast (C. albicans and $A$. niger). The application of these MPs led to increased levels of ROS and first-line defense antioxidants, such as superoxide dismutase and glutathione peroxidase, which could lead to biomedical applications in implant-related infections [93].

Due to their difference in size, MPs take more time to dissolve than NPs; therefore, they release fewer metal ions in the same period of time. As such, NPs usually present a better alternative with stronger and better antimicrobial effects $[10,93]$.

\section{Antimicrobial Surfaces and Coatings}

As mentioned above, pathogen resistance has prompted the development of antimicrobial surfaces. A variety of inorganic materials (namely metals, metalloids, metal alloys, metal ions and oxides) can be used to grant surfaces effective antimicrobial properties [1,94]. In fact, not only can they be used as alternative antimicrobial materials, but they are also advantageous as they present more stable antimicrobial action and are a "green" approach (eco-friendly) when compared to polymers and chemical surfaces [1].

To fight these multi-resistant infections, the propagation of pathogens needs to be stopped. For this matter, several researchers have developed different antimicrobial surfaces with biocidal and/or anti-adhesive properties [95,96].

Amongst the wide range of metals, $\mathrm{Cu}$ and $\mathrm{Ag}$ are the two most commonly used, with proven antimicrobial properties, such as the ability to effectively inhibit and kill different bacterial and viral strains upon direct contact, either as coatings or as the surface material itself $[97,98]$. This happens due to the release of metallic ions that become toxic to microorganisms at high concentrations, leading to membrane rupture and, therefore, cell death. Between both metals, $\mathrm{Cu}$ proves to be advantageous compared to Ag, as it exhibits the best antimicrobial results and is also cheaper to acquire. For this reason, a large number of $\mathrm{Cu}$-containing surfaces have been studied and been registered to have antimicrobial activity against several microorganisms $[1,94,96,98]$. Several applications for $\mathrm{Cu}$ surfaces, as well as for other kinds of metallic surfaces with proven results on the different microorganism reductions are described below:

Healthcare applications

Metals have been used for healthcare applications to prevent the spread and promote dead of pathogens over human history. In this context, several researchers have been studying the effect of metallic surfaces when in contact with different pathogens. For example, Noyce and co-workers compared the antiviral effect of $\mathrm{Cu}$ and stainless-steel surfaces by inoculating the Influenza A virus in sterile coupons of both metals for periods between 1 and $24 \mathrm{~h}$ [99]. After, the number of viral particles that remained infectious after the incubation process was determined, resulting in a $75 \%$ reduction of active virus after 24 $\mathrm{h}$ with stainless steel. Cu managed the same reduction (75\%) in just $1 \mathrm{~h}$, further reducing the number of infectious viruses to under $0.1 \%$ after $6 \mathrm{~h}$ of initial inoculation, emphasizing $\mathrm{Cu}^{\prime} \mathrm{s}$ great antimicrobial potential [90]. In another study, Warnes and collaborators investigated the antiviral activity of a wide range of $\mathrm{Cu}$-containing alloys, including $\mathrm{Cu}-\mathrm{Nis}$ and brasses, as well as $\mathrm{Cu}, \mathrm{Ni}$, and $\mathrm{Zn}$ in their pure metal forms (as controls) against human coronavirus 229E (HuCoV-229E) [100]. To investigate the antiviral effects of these metals, they spread $\mathrm{HuCoV}-229 \mathrm{E}$ over $1 \mathrm{~cm}^{2}$ coupons of the various test surfaces before incubating at room temperature for different periods of time. Their main results indicated that plain $\mathrm{Cu}$, brasses 
containing over $70 \% \mathrm{Cu}$, and $\mathrm{Cu}-\mathrm{Nis}$ with over $90 \% \mathrm{Cu}$, displayed the best antiviral effects against $\mathrm{HuCoV}-229 \mathrm{E}$, as some of the alloys completely inactivated $100 \%$ of the inoculated virus after only $20 \mathrm{~min}$ of exposure [100]. Coincidently, some of the alloys used against $\mathrm{HuCoV}-229 \mathrm{E}$ were also used against E. coli $\mathrm{O} 157$ by Wilks and co-workers under similar conditions (using metal coupons) and the results obtained against these Gram-negative bacteria were similar to those observed against the virus [101]. C21000 $(95 \% \mathrm{Cu})$ and $\mathrm{C} 23000(85 \% \mathrm{Cu})$ alloys, which were used in both cases, showed some of the best antiviral and antibacterial results in their respective works. C21000 managed to completely eradicate $\mathrm{HuCoV}-229 \mathrm{E}$ in $20 \mathrm{~min}$, while it took a little longer to kill $100 \%$ of E. coli O157 (90 min). As for $\mathrm{C} 23000$, total microbial eradication was achieved after $60 \mathrm{~min}$ for both $\mathrm{HuCoV}-229 \mathrm{E}$ and E. coli O157, displaying the best antibacterial activity in the corresponding study $[99,101]$. These results indicate that brasses containing over $85 \% \mathrm{Cu}$ could be a viable option for the fabrication of antimicrobial surfaces for general use.

The antimicrobial activity of $\mathrm{Cu}$ is effective against several pathogenic microorganisms, namely bacteria and viruses, as evidenced in this review paper. However, $\mathrm{Cu}^{\prime}$ s inhibitory effect against pathogens also extends to fungi. Ballo and collaborators described the fungicidal activity of $\mathrm{Cu}$-coated surfaces against azole-resistant C. albicans and C. glabrata [96]. In this study, Cu-sputtered polyester surfaces (Cu-PES) and uncoated PES (control) were used and inoculated with the above-mentioned fungal strains, for different periods $(15,30$, or $60 \mathrm{~min}$ ) at room temperature and under either dark or actinic light. The authors found that Cu-PES displayed fungicidal activity against both C. albicans and C. glabrata under dark and actinic light conditions within $60 \mathrm{~min}$ [96].

Recently, the SARS-CoV-2 pandemic hit the globe, becoming a main focus for science to determine how to prevent its spread. Concerning this, several researchers worldwide started to work hard on this problem. Among them, Hutasoit and collaborators explored the viricidal activity of cold-sprayed Cu-coated surfaces against SARS-CoV-2 in an attempt to slow the dissemination of this virus (as well as other viruses) [102]. The cold-spray coating method used in their work is highly advantageous because it allows a very rapid coating "treatment" of commonly touched steel surfaces, which is faster and cheaper than replacing every single one of these surfaces that are touched by the public. This cold-spray technique consists of propulsion of metal particles at supersonic speeds onto surfaces due to a highly pressurized carrier gas, forming a thin dense metal layer. For antiviral testing, a push plate was subjected to an annealing treatment $(\mathrm{Cu} \mathrm{A})$ while another was tested without further treatments $(\mathrm{Cu} \mathrm{N})$. After preliminary tests, they proceeded to study the viricidal effect of $\mathrm{Cu}$ coating by placing SARS-CoV-2 on small squares of $\mathrm{Cu}(\mathrm{Cu} \mathrm{N})$, stainless steel and activated $\mathrm{Cu}(\mathrm{Cu} \mathrm{A})$ at room temperature at different times $(1,10,30,120$ and $300 \mathrm{~min}$ ). Their main results showed a $96 \%$ viral inactivation after $2 \mathrm{~h}$ of exposure to the $\mathrm{Cu} \mathrm{N}$ coating and a $92 \%$ inactivation on the $\mathrm{Cu}$ A coating after the same exposure time. After $5 \mathrm{~h}$ of contact, the viral inactivation efficiency increased to $99.2 \%$ and $97.9 \%$, for the respective coatings [102].

Other researchers have also studied surfaces with physical and/or chemical modifications. As an example, Selvamani and collaborators demonstrated the antimicrobial properties of a laser textured $\mathrm{Cu}(\mathrm{LT}-\mathrm{Cu})$ surface and its efficiency against pathogenic bacteria, such as methicillin-resistant S. aureus (MRSA), P. aeruginosa, S. aureus, and E. coli, at different concentrations [1]. According to their findings, the LT-Cu process enhanced the bactericidal properties of the surfaces, achieving total eradication of E. coli after $120 \mathrm{~min}$ of direct exposure. Moreover, they studied the bacterial killing potential of simple (not modified) $\mathrm{Cu}$ surfaces and LT-Cu surfaces by dipping both surfaces in PBS (phosphatebuffered saline) with two multidrug-resistant bacterial strains (MRSA and P. aeruginosa) and found that LT-Cu surfaces completely eradicated P. aeruginosa and MRSA after 40 and 90 min of exposure, respectively. The pristine Cu surfaces also killed $100 \%$ of both strains but at a slower pace. These authors found that, when higher concentrations of S. aureus and E. coli were applied, only LT-Cu surfaces were able to eradicate them (at 120 and $60 \mathrm{~min}$ of exposure). Moreover, the LT-Cu process used by these researchers produced micro and 
mesoporous structures, which in turn granted anti-adhesive properties to the surfaces that might have helped to improve their antibacterial activity [1].

Taking the above-mentioned into account, and to create the "ultimate" antimicrobial surface, a combination of anti-adhesive surfaces and biocidal agents was proposed by Ellinas and co-workers, as well as Kefallinou and co-workers, due to the limitations of both types of surfaces when used separately (e.g., biofilm formation reduces the biocidal activity of surfaces without anti-adhesive properties, while in anti-adhesive surfaces with no biocidal agents the anti-adhesive properties are lost over time, as the few attached microorganisms grow and form biofilms) [4,95]. These works consist in the development and study of the antimicrobial activity of micro-nanotextured superhydrophobic poly(methyl methacrylate) (PMMA) surfaces complemented with sputtered $\mathrm{Cu}$ and $\mathrm{Ag}$ coatings, which they referred to as "hybrid" surfaces. Overall, amongst several tests and comparisons between surfaces, they concluded that $\mathrm{Cu}$ was the best bactericidal agent and the $\mathrm{Cu}$-coated superhydrophobic PMMA surface achieved the best antibacterial activity, as it demonstrated antimicrobial action against Synechococcus spp. PCC7942 (at one of the highest concentrations ever reported) [4,95].

Food industry and other applications

Metal surfaces and coatings have also been widely applied in the food industry as an attempt to fight cross-contamination (which commonly occurs between food, surfaces, and equipment). Concerning this, Akhidime and co-workers studied the leaching potential of $\mathrm{Ag}, \mathrm{Ti}, \mathrm{Cu}, \mathrm{Fe}$, molybdenum, and $\mathrm{Zn}$ into media and its effect against $\mathrm{S}$. aureus, E. coli and L. monocytogenes, with silicon substrates as base surfaces (control) [97]. One of their antibacterial studies was conducted by submerging metal-coated surfaces into bacterial suspensions and registering the number of viable cells over time via plate counts. Among the main results, it was possible to observe that the biggest leaching behavior was obtained for $\mathrm{Cu}$ followed by $\mathrm{Zn}$. Surprisingly, Ag demonstrated one of the lowest leaching behaviors. However, despite Ag's leaching potential being 350 times lower than $\mathrm{Cu}, \mathrm{Ag}$ displayed one of the best antimicrobial effects. Cu's antibacterial potential was the greatest, killing $99 \%$ of the three bacterial species after just one hour of incubation. In the same period, Ag managed to kill $46 \%, 99 \%$, and $34 \%$ of S. aureus, E. coli, and L. monocytogenes, respectively. Overall, $\mathrm{Cu}$ was the coating with the best antimicrobial activity, followed by Ag as the second-best coating against the three pathogenic bacterial species tested (E. coli, S. aureus, and L. monocytogenes) [97].

Another approach to the treatment of fungal infections using metals was presented by Bastos and co-workers with a study of the antimicrobial effect of gallium (gallium nitrate III, $\left.\left[\mathrm{Ga}\left(\mathrm{NO}_{3}\right)_{3}\right]\right)$ against different fungal pathogens, namely azole-resistant $A$. fumigatus and different species of Candida spp [103]. They performed a fungal killing assay by testing different concentrations of $\mathrm{Ga}\left(\mathrm{NO}_{3}\right)_{3}$ against various strains. For this, inoculated microplates were incubated at $37^{\circ} \mathrm{C}$ for $2,8,16,24$, and $48 \mathrm{~h}$ in different media, and samples of each time were taken to measure cell viability. Based on their results, the researchers concluded that the antifungal activity of gallium is dependent on the Fe concentration in the medium, as gallium's MIC increased (or no antifungal effect was obtained) when Fe-containing media were used [103].

Despite all the above-mentioned information, metal surfaces and coatings alone are not the sole options for the development of antimicrobial surfaces. Wettability is a property of materials that have been extensively studied to accomplish antimicrobial surfaces, through either super hydrophobicity or super hydrophilicity, due to their ability to reduce microbial adhesion [1,103]. When pathogenic adhesion is reduced, further growth and dissemination are hindered, which passively prevents infections $[4,95,103]$. Moreover, roughness can also cause a surface to become superhydrophobic, due to the entrapment of air between roughened structures when a liquid comes in contact with the solid surface. This entrapped air has an anti-adhesive effect that hinders microbial adhesion, as it reduces the area available for microorganisms to attach, therefore minimizing adhesion to surfaces with moderate wettability, such as food or food packaging [104]. 
Table 3 presents a summary of several studies using different approaches for the development of antimicrobial surfaces.

Table 3. Different approaches for the development of metallic antimicrobial surfaces to be applied in healthcare, food industry, and others.

\begin{tabular}{|c|c|c|c|c|c|c|}
\hline Surface & Coating Method & Metals & Strains & Applications & Main Results & Reference \\
\hline \multicolumn{7}{|c|}{ Healthcare } \\
\hline $\begin{array}{l}\text { "Hybrid" } \\
\text { nanostructured } \\
\text { superhydrophobic } \\
\text { PMMA surfaces }\end{array}$ & Sputtering & $\mathrm{Ag}, \mathrm{Cu}$ & $\begin{array}{l}\text { Synechococcus sp. } \\
\text { PCC7942 } \\
\text { (cyanobacteria) }\end{array}$ & $\begin{array}{l}\text { Hospital, } \\
\text { domestic and } \\
\text { public surfaces }\end{array}$ & $\begin{array}{l}\text { Metal-sputtered } \\
\text { superhydrophobic surfaces } \\
\text { able to promote bacterial } \\
\text { repulsion and killing } \\
\text { efficacy (due to the Ag and } \\
\mathrm{Cu} \text { ions). }\end{array}$ & {$[4,95]$} \\
\hline $\begin{array}{l}\text { Polyester surfaces } \\
\text { (PES) }\end{array}$ & Sputtering & $\mathrm{Cu}$ & $\begin{array}{l}\text { C. albicans and } C . \\
\text { glabrata }\end{array}$ & Hospital surfaces & $\begin{array}{l}\text { Cu-PES displayed } \\
\text { fungicidal activity against } \\
\text { C. albicans and C. glabrata } \\
\text { within } 60 \text { min. }\end{array}$ & [96] \\
\hline $\begin{array}{l}\text { Polydopamine- } \\
\text { coated Ti } \\
\text { implants }\end{array}$ & $\begin{array}{l}\text { Spin/spray } \\
\text { coating }\end{array}$ & $\begin{array}{l}\mathrm{Ag}^{+}, \mathrm{Cu}^{2+}, \mathrm{Sr}^{2+}, \\
\mathrm{Zn}^{2+}\end{array}$ & $\begin{array}{l}\text { E. coli and } S . \\
\text { aureus }\end{array}$ & $\begin{array}{l}\text { Dental and } \\
\text { orthopaedic } \\
\text { prostheses for } \\
\text { implants }\end{array}$ & $\begin{array}{l}\text { All ion coatings showed } \\
\text { antibacterial activity, } \\
\text { reducing the viability of } \\
\text { the tested species by over } \\
85 \% \text { after } 3 \text { h of contact. }\end{array}$ & [105] \\
\hline $\begin{array}{l}\text { Laser textured Cu } \\
\text { surfaces (LT-Cu) }\end{array}$ & (no coating) & $\mathrm{Cu}$ & $\begin{array}{l}\text { MRSA, } P \text {. } \\
\text { aeruginosa, } S \text {. } \\
\text { aureus and } E . \text { coli }\end{array}$ & $\begin{array}{l}\text { Biomedical } \\
\text { surfaces (e.g., } \\
\text { hospital handrails } \\
\text { and doorknobs) }\end{array}$ & $\begin{array}{l}\text { LT-Cu eradicated } P \text {. } \\
\text { aeruginos } a \text { and MRSA, E. } \\
\text { coli and } S . \text { aureus in } 40,90, \\
60 \text { and } 120 \text { min, } \\
\text { respectively. }\end{array}$ & [1] \\
\hline $\begin{array}{l}\text { Cu and stainless } \\
\text { steel surfaces }\end{array}$ & (no coating) & $\mathrm{Cu}$ & Influenza A & $\begin{array}{l}\text { Surfaces for } \\
\text { schools and health } \\
\text { care units }\end{array}$ & $\begin{array}{l}\text { Cu inactivated } 75 \% \text { of } \\
\text { Influenza A just } 1 \mathrm{~h}, \\
\text { whereas, after } 6 \mathrm{~h}, \mathrm{Cu} \\
\text { presented }>99.9 \% \\
\text { viral inactivation. }\end{array}$ & [99] \\
\hline \multicolumn{7}{|c|}{ Food industry and Other applications } \\
\hline Silicon substrates & Sputtering & $\begin{array}{l}\mathrm{Ag}, \mathrm{Ti}, \mathrm{Cu}, \mathrm{Fe}, \mathrm{Mo}, \\
\mathrm{Zn}\end{array}$ & $\begin{array}{l}\text { L. monocytogenes, } \\
\text { E. coli and } \\
\text { S. aureus }\end{array}$ & Food industries & $\begin{array}{l}\text { Cu killed } 99 \% \text { of all the } \\
\text { three strains of bacteria, } \\
\text { followed by Ag which } \\
\text { killed } 36,99 \text { and } 34 \% \text { of } S \text {. } \\
\text { aureus, E. coli and L. } \\
\text { monocytogenes, respectively. } \\
\text { Zn also significantly } \\
\text { decreased cell viability of } \\
\text { the three strains, Mo and } \\
\text { Fe were only effective in } \\
\text { killing S. aureus and } L \text {. } \\
\text { monocytogenes, whilst Ti } \\
\text { was only able to kill } S \text {. } \\
\text { aureus. }\end{array}$ & [97] \\
\hline $\begin{array}{l}\text { Wide range of } \\
\mathrm{Cu} \text {-containing } \\
\text { alloys }(\mathrm{Cu}, \\
\text { brasses, bronzes, } \\
\text { Cu Nis and } \\
\mathrm{Cu}-\mathrm{Ni}-\mathrm{Zn} \text { alloys) }\end{array}$ & - & $\begin{array}{l}\mathrm{Cu}, \mathrm{Zn}, \mathrm{Sn}, \mathrm{Ni}, \mathrm{Al}, \\
\mathrm{Mn}, \mathrm{Fe}, \mathrm{Cr}, \mathrm{P}, \mathrm{Si} \\
\mathrm{Ti}, \mathrm{Mg} \\
\text { (in the alloys) }\end{array}$ & E. coli O157:H7 & $\begin{array}{l}\text { Food industries } \\
\text { and domestic } \\
\text { work surfaces }\end{array}$ & $\begin{array}{l}19 \text { out of } 21 \text { tested alloys } \\
\text { eradicated E. coli O157 } \\
\text { between } 1 \text { to } 6 \text { h of contact. } \\
\text { Plus, a correlation between } \\
\text { Cu content and decreased } \\
\text { E. coli O157 survival time } \\
\text { was found in the bronzes. }\end{array}$ & [101] \\
\hline $\begin{array}{l}\text { Wide range of } \\
\text { Cu-containing } \\
\text { alloys (Cus, } \\
\text { brasses and other } \\
\text { alloys) }\end{array}$ & (no coating) & $\begin{array}{l}\mathrm{Cu}, \mathrm{Zn}, \mathrm{Ni}, \mathrm{Sn}, \mathrm{Fe}, \\
\mathrm{Cr}, \mathrm{Mn} \\
\text { (in the alloys) }\end{array}$ & $\mathrm{HuCoV}-229 \mathrm{E}$ & Public surfaces & $\begin{array}{l}\mathrm{Cu}, \text { brasses with } \mathrm{Cu}>70 \% \\
\text { and } \mathrm{Cu}-\mathrm{Ni} \text { alloys with } \mathrm{Cu} \\
>90 \% \text { had the best } \\
\text { virucidal activity, } \\
\text { eradicating } \mathrm{HuCoV}-229 \mathrm{E} \\
\text { in } 20-60 \text { min. } \mathrm{Cu} \text { ions and } \\
\text { ROS formation were } \\
\text { responsible for inactivating } \\
\text { the virus. }\end{array}$ & [100] \\
\hline $\begin{array}{l}\text { Stainless steel } \\
\text { touch surfaces }\end{array}$ & $\begin{array}{l}\text { Cold-spray } \\
\text { coating }\end{array}$ & $\mathrm{Cu}$ & $\begin{array}{l}\text { SARS-CoV-2 } \\
\text { (COVID-19) }\end{array}$ & $\begin{array}{l}\text { Touch surfaces } \\
\text { (e.g.; } \\
\text { stainless-steel } \\
\text { door push plates) }\end{array}$ & $\begin{array}{l}\text { Cu inactivated } 96 \% \text { of the } \\
\text { virus in the first } 2 \mathrm{~h} \text { of } \\
\text { contact and nearly } \\
\text { eradicated it after } 5 \mathrm{~h} \\
\text { presenting an inactivation } \\
\text { of } 99.2 \% \text {. }\end{array}$ & {$[102]$} \\
\hline $\begin{array}{l}\text { In vitro test } \\
\text { (microplates) }\end{array}$ & (no coating) & $\mathrm{Ga}^{3+}$ & $\begin{array}{l}\text { Aspergillus spp. } \\
\text { and Candida spp. }\end{array}$ & $\begin{array}{l}\text { Antifungal } \\
\text { therapy }\end{array}$ & $\begin{array}{l}\text { Ga displayed potent } \\
\text { antifungal potential. }\end{array}$ & [103] \\
\hline
\end{tabular}




\section{Synergic Combination with Drugs}

Metallic particles could work with standard drugs to increase their antimicrobial activity. Moreover, the majority of practical trials in the literature regarding the synergistic effect between metals and drugs use Ag-NPs combined with antibiotics. Figure 2 presents an example of the combined action of antibiotics with Ag-NPs. M-NPs can disrupt the bacterial membrane of both Gram-negative (left) and Gram-positive (right) bacteria, enabling the entrance of antibiotics into the cell and leading to DNA damage. Moreover, the combined action of antibiotics with M-NPs induces oxidative stress and creates ROS; consequently, it also damages the bacterial DNA (as noted above) [106-111].

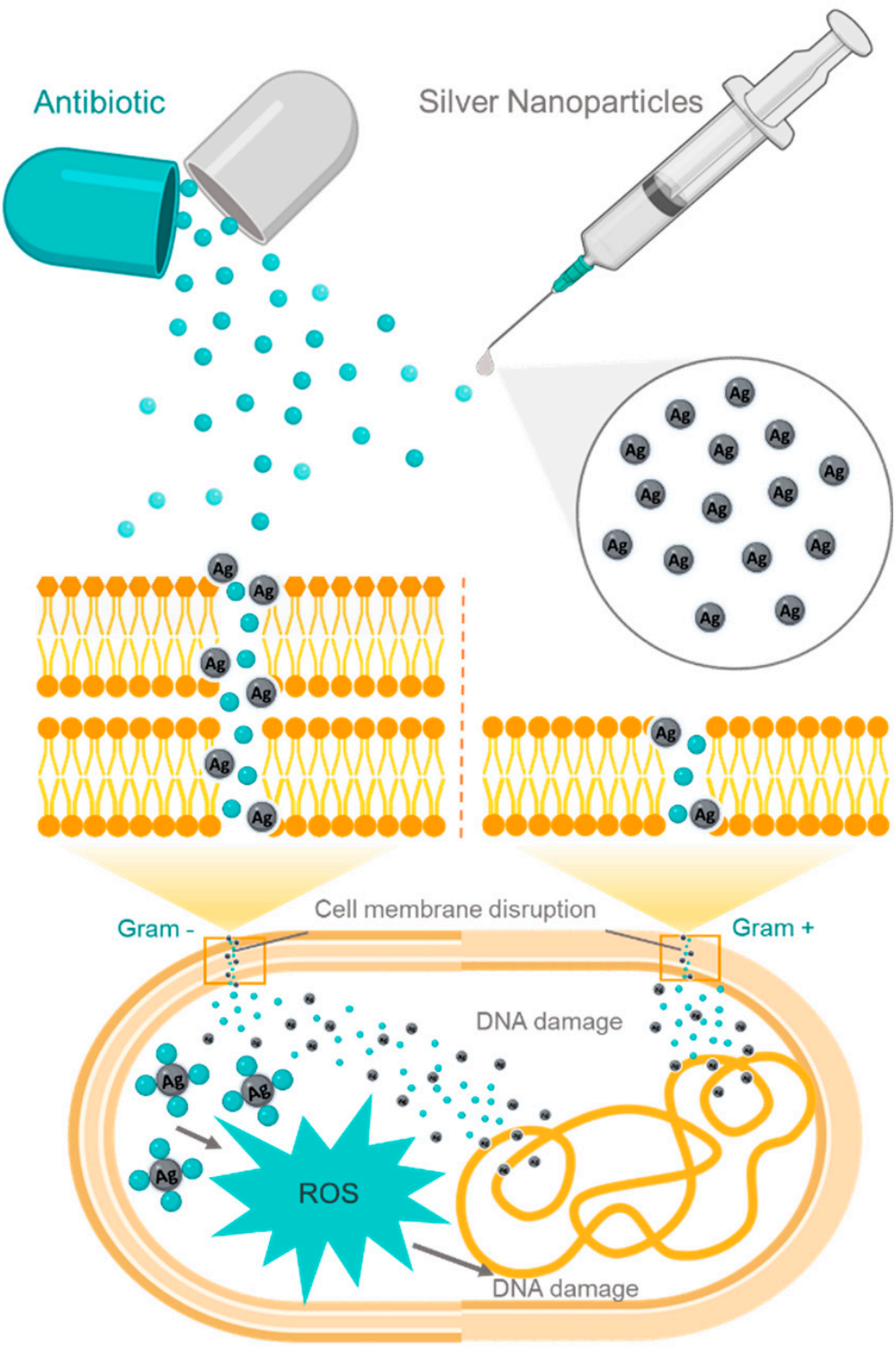

Figure 2. Representative illustration of the interaction between antibiotics and Ag-NPs and their combined action inside both Gram-negative (left) and Gram-positive (right) bacteria. Although there is a thicker path for Ag-NPs and antibiotics to travel through with the Gram-negative bacteria membrane, once, inside the cell, the mechanisms are the same as for Gram-positive bacteria: accumulation of particles inside the cell; production of ROS; and ultimately cell death by damaging the bacterial DNA (adapted from [111]).

This effect, increased by the dual antimicrobial vehicles produced using M-NPs and different drugs, has already been demonstrated by several authors, as presented in Table 4 . 
Some authors have studied the synergy of M-NPs in combination with antibiotics, such as amoxicillin and polymyxin B, and found higher bactericidal activity by binding AgNPs with these antibiotics [112,113]. For example, Abo-Shama and co-workers detected the antimicrobial activity of Ag-NPs and ZnO-NPs alone and combined with a range of antibiotics [114]. From nearly all the different antibiotic classes against Gram-positive and Gram-negative bacteria (S. aureus, E. coli, Salmonella spp. and C. albicans), their findings showed that the combination of Ag-NPs with some of the tested antibiotics presented a better synergistic effect than ZnO-NPs with the same antibiotics [114]. In addition, Vazquez-Muñoz and collaborators evaluated the antimicrobial activity of Ag-NPs combined with several antibiotics, such as chloramphenicol, kanamycin, ampicillin, aztreonam, and biapenem in both Gram-positive and Gram-negative bacteria [106]. They determined that Ag-NPs change the cell membrane integrity and increase cell permeability, enabling antibiotics intracellular access, which will enhance the efficiency of the antibiotics on their intracellular targets [106].

In another study, Pereira and co-workers produced chitosan microspheres and evaluated their efficiency in the adsorption of Ag ions for the formation of NPs [115]. Then, they evaluated the bactericidal activity and potential as a system for the release of ibuprofen. They found that the concentration of ibuprofen retained in chitosan microspheres was higher than in Ag-NPs microspheres, which indicates that microspheres with Ag-NPs released more drug $(77 \%)$, exhibiting bactericidal characteristics and a greater drug release capacity than the material without Ag-NPs [115].

Table 4. Synergistic interactions between different types of M-NPs and drugs.

\begin{tabular}{|c|c|c|c|c|c|}
\hline NPs & Type of Drug & Strains & Mechanism of interaction & Main Results & Reference \\
\hline & \multicolumn{5}{|l|}{ Antibacterial } \\
\hline \multirow[t]{4}{*}{$\mathrm{Ag}$} & tetracycline, neomycin & $\begin{array}{l}\text { S. typhimurium } \\
\text { DT104. }\end{array}$ & $\begin{array}{l}\text { The complex formed between } \\
\text { drugs and Nps might be } \\
\text { produced due to interactions } \\
\text { established between the } \\
\text { positively charged Ag-NPs and } \\
\text { the large amount of OH groups } \\
\text { found in the composition of } \\
\text { both antibiotics, which provides } \\
\text { them with a negative charge. } \\
\text { Additionally, Tetracycline and } \\
\text { Neomycin can bind to the } \\
\text { bacteria's membrane proteins. }\end{array}$ & $\begin{array}{l}\text { Tetracycline alone in concentration } \\
\text { ranges of } 0.01-1.25 \mu \mathrm{g} / \mathrm{mL} \text { does not } \\
\text { inhibit bacterial growth, neither } \\
\text { neomycin in ranges of } 0-9.6 \mu \mathrm{g} / \mathrm{mL} \text {. } \\
\text { Ag-NPs alone at } 5 \mu \mathrm{g} / \mathrm{mL} \text { can cause up } \\
\text { to } 30 \% \text { of inhibition after } 2 \mathrm{~h} \text { of exposure. } \\
\text { Tetracycline combined with Ag-NPs } \\
\text { inhibit bacterial growth by } 85 \% \text { with an } \\
\mathrm{IC}_{50} \text { of } 0.07 \mu \mathrm{g} / \mathrm{mL} \text { after } 2 \mathrm{~h} \text { of exposure. } \\
\text { Neomycin combined with Ag-NPs } \\
\text { presents an } \mathrm{IC}_{50} \text { of } 0.43 \mu \mathrm{g} / \mathrm{mL} \text { after } 2 \mathrm{~h} \\
\text { of exposure. }\end{array}$ & [112] \\
\hline & $\begin{array}{l}\text { streptomycin, amikacin, } \\
\text { kanamycin, vancomycin, } \\
\text { tetracycline, ampicillin, } \\
\text { cefepime, amoxicillin, } \\
\text { cefetaxime }\end{array}$ & $\begin{array}{l}\text { S. epidermidis, } \\
\text { Serratia marcescens, } \\
\text { E. coli, } S \text {. } \\
\text { typhimurium, K. } \\
\text { pneumonia, B. } \\
\text { cereus, S. aureus and } \\
\text { B. subtilis. }\end{array}$ & $\begin{array}{l}\text { Antibiotics and NPs were used } \\
\text { individually and not } \\
\text { complexed. }\end{array}$ & $\begin{array}{l}\text { The studied bacteria were found to be } \\
\text { inhibited in the presence of the AgNPs } \\
\text { and antibiotics combination, which } \\
\text { otherwise showed a resistant pattern in } \\
\text { the presence of antibiotics (vancomycin, } \\
\text { cefetaxime, ampicillin, kanamycin, } \\
\text { amikacin, cefepime) alone. }\end{array}$ & [116] \\
\hline & $\begin{array}{l}\text { bacitracin, kanamycin, } \\
\text { gentamicin, streptomycin, } \\
\text { erythromycin, } \\
\text { chloramphenicol }(\mathrm{Ch})\end{array}$ & $\begin{array}{l}\text { B. subtilis, E. coli, } \\
\text { S.aureus and K. } \\
\text { pneumoniae. }\end{array}$ & $\begin{array}{l}\text { Ag-NPs and antibiotic } \\
\text { conjugates can be obtained } \\
\text { through electrostatic } \\
\text { interactions. It is also possible } \\
\text { to have hydrophobic } \\
\text { interactions as well as covalent } \\
\text { bonds between the NPs and } \\
\text { sulfhydryl groups (-SH) present } \\
\text { on the antibiotics. }\end{array}$ & $\begin{array}{l}\text { For all the bacteria strains, an overall } \\
\text { percentage of synergistic bacterial effect } \\
\text { between Ag-NPs and antibiotics was } \\
\text { observed with 16,11.5, 10, 87, } 9.4 \text { and } \\
9.7 \% \text { for kanamycin, gentamicin, } \\
\text { streptomycin, bacitracin, ch and } \\
\text { erythromycin, respectively. }\end{array}$ & [117] \\
\hline & chloramphenicol & $\begin{array}{l}\text { B. cereus, B. subtilis, } \\
\text { S. aureus, C. rubrum, } \\
\text { E. coli, P. areuginosa, } \\
\text { S.a typhimurium } \\
\text { and K. pneumoniae. }\end{array}$ & $\begin{array}{l}\text { The bonding reaction between } \\
\text { the antibiotics and AgNPs } \\
\text { could occur due to the } \\
\text { chelation process. }\end{array}$ & $\begin{array}{l}\text { The MIC values ranged from } 0.312-2.5 \\
\text { and } 1.25-2.5 \mathrm{mg} / \mathrm{mL} \text { and the } \mathrm{MBC} \\
\text { values ranged from } 2.5->10 \text { and } \\
5-10 \mathrm{mg} / \mathrm{mL} \text { for } \mathrm{Ag}-\mathrm{NPs} \text { and } \mathrm{Ch} \text {, } \\
\text { respectively. However, when combined, } \\
\text { the } \mathrm{MIC} \text { and } \mathrm{MBC} \text { values decreased for } \\
0.078-0.625 \text { (Ag) and } 1.25-10 \mathrm{mg} / \mathrm{mL} \\
(\mathrm{Ch}) \text {, respectively. }\end{array}$ & [118] \\
\hline
\end{tabular}


Table 4. Cont.

\begin{tabular}{|c|c|c|c|c|c|}
\hline NPs & Type of Drug & Strains & Mechanism of interaction & Main Results & Reference \\
\hline $\mathrm{Au}$ & $\begin{array}{l}\text { cefotaxime and } \\
\text { ciprofloxacin }\end{array}$ & $\begin{array}{l}\text { S. typhimurium, S. } \\
\text { typhi and Salmonella } \\
\text { enteritidis. }\end{array}$ & $\begin{array}{l}\text { Antibiotics and Au-NPs were } \\
\text { not complexed. However, the } \\
\text { mutual delivery of both species } \\
\text { enabled a combined effect of } \\
\text { ROS accumulation from the } \\
\text { antibiotics effect and membrane } \\
\text { disruption, inducing apoptosis } \\
\text { due to Au-NPs presence. }\end{array}$ & $\begin{array}{l}\text { S. typhimurium: the MIC value for } \\
\text { Au-NPs, cefotaxime and ciprofloxacin } \\
\text { alone was } 2.5 \mu \mathrm{g} / \mathrm{mL} \text { for all. When } \\
\text { combined the MIC values were } 0.65 \\
\mu \mathrm{g} / \mathrm{mL} \text { for Au-NPs and cefotaxime and } \\
0.32 \mu \mathrm{g} / \mathrm{mL} \text { for Au-NPs } \\
\text { and ciprofloxacin. } \\
S \text {. typhi: the MIC values were } 5 \mu \mathrm{g} / \mathrm{mL} \\
\text { for Au-NPs and cefotaxime alone and } \\
2.5 \mu \mathrm{g} / \mathrm{mL} \text { for ciproflaxin alone. When } \\
\text { combined the MIC values were } 0.65 \\
\mu \mathrm{g} / \mathrm{mL} \text { for Au-NPs and cefotaxime and } \\
1.3 \mu \mathrm{g} / \mathrm{mL} \text { for Au-NPs } \\
\text { and ciprofloxacin. }\end{array}$ & [119] \\
\hline
\end{tabular}

$\begin{array}{lll}\mathrm{Cu} & \text { benzalkonium chloride } & \text { E. coli ATCC 25922, } \\ & \text { S. aureus } M R S A \\ & & 33591 \text { and } S . \text { aureus } \\ & \text { MRSA 25923. }\end{array}$

Cu-NPs were prepared by electrochemical synthesis and stabilized by sacrificial anode electrolysis method with benzalkonium chloride, forming core-shell $\mathrm{Cu}$-NPs with $\mathrm{BAC}$ as a capping agent.

The obtained results showed an uncountable number of colony-forming units (CFU) for $\mathrm{Cu}^{2+}$ salt $\left(\mathrm{CuCl}_{2}\right)$, $\mathrm{Cu}-\mathrm{NPs}$ stabilized with butyl-ammonium perchlorate and tetra-butyl-ammonium perchlorateand; 230 CFUs for BAC alone and 0 CFUs for Cu-NPs combined with BAC.

Also, the MIC values for $\mathrm{Cu}$-NPs and BAC combinations are 12.5, $<1$ and $3.125 \mu \mathrm{g} / \mathrm{mL}$ for E. coli ATCC 25922 S. aureus MRSA 33591 and S. aureus MRSA 25923, respectively.

ampicillin, amoxicillin, E. coli, S. typhi, gentamicin and Micrococcus luteus ciprofloxacilin and S. mutans
The metallic $\mathrm{Cu}$ is known to react with active groups, like amido and hydroxyl, which are present in antibiotic molecules, leading to a synergism between $\mathrm{Cu}-\mathrm{NPs}$ and antibiotics.

ZnO-NPs were functionalized with glutamic acid and conjugated with thiosemicarbazide, which can react as a chelating ligand.

In this case, $\mathrm{ZnO}-\mathrm{NPs}$ and ciprofloxacin did not form a complex, but instead, functionalized $\mathrm{ZnO}-\mathrm{NPs}$

damaged the bacterial membrane and removed essential metal ions present on the cell surface by chelation, disrupting the membrane permeability, and allowing ciprofloxacin to enter the bacterial cell.

octadecanethiol (ODT) S. aureus and E. coli. $\quad$ ZnO-NPs and ODT were not complexed.

Possibly, ODT molecules facilitated the dispersion of $\mathrm{ZnO}-\mathrm{NPs}$ at the fabric's surface, preventing the formation of agglomerations.

\author{
S. aureus: For the ODT and ZnO-NPs \\ alone, the $\mathrm{CFU} / \mathrm{m}^{2}$ count was 312000 \\ and 4440, respectively. Whereas for the \\ combination of ODT plus ZnO-NPs, the \\ $\mathrm{CFU} / \mathrm{m}^{2}$ count was 600 . \\ E. coli: For the ODT and ZnO-NPs alone, \\ the $\mathrm{CFU} / \mathrm{m}^{2}$ count was 49800 and 1800 , \\ respectively. Whereas for the \\ combination of ODT plus ZnO-NPs, the \\ $\mathrm{CFU} / \mathrm{m}^{2}$ count was 48 \\ The combination of ZnO-NPs and the \\ surfactant ODT significantly diminished \\ the bacterial adhesion.
}


Table 4. Cont.

\begin{tabular}{|c|c|c|c|c|}
\hline NPs Type of Drug & Strains & Mechanism of interaction & Main Results & Reference \\
\hline $\mathrm{MgO}$ nisin & $\begin{array}{l}\text { E. coli and } \\
\text { Salmonella stanley. }\end{array}$ & $\begin{array}{l}\text { The synergistic effect of } \\
\text { MgO-NPs and nisin is not clear. } \\
\text { However, nisin treatment might } \\
\text { have been responsible for the } \\
\text { rupture of large pores in the } \\
\text { bacterial cell membrane, } \\
\text { allowing the entering of } \\
\text { MgO-NPs into the cell, which } \\
\text { can produce ROS and damage } \\
\text { the bacterial DNA. }\end{array}$ & $\begin{array}{l}\text { E. coli: the logarithmic CFU/mL levels } \\
\text { were approximately } 3 \text { and } 4 \text { when } 25 \\
\mathrm{mg} / \mathrm{mL} \text { of nisin and } 4 \mathrm{mg} / \mathrm{mL} \text { of } \\
\text { MgO-NPs, respectively, were } \\
\text { administrated alone. Whereas, when } \\
\text { they were administrated together, the } \\
\text { logarithmic CFU/mL level came down } \\
\text { to approximately } 1 \text {. } \\
\text { S.stanley: the logarithmic CFU } / \mathrm{mL} \\
\text { levels were approximately } 3 \mathrm{and} 4 \text { when } \\
25 \mathrm{mg} / \mathrm{mL} \text { of nisin and } 4 \mathrm{mg} / \mathrm{mL} \text { of } \\
\text { MgO-NPs, respectively, when } \\
\text { administrated alone. Whereas, when } \\
\text { they were administrated together, the } \\
\text { logarithmic CFU/mL level came down } \\
\text { to approximately below } 3 \text {. }\end{array}$ & [124] \\
\hline
\end{tabular}

\begin{tabular}{lll}
\hline Antifungal & \\
\hline Ag Amphotericin B (AmB) & $\begin{array}{l}\text { C. albicans, } C . \\
\text { glabrata and C. } \\
\text { neoformans. }\end{array}$ & $\begin{array}{l}\text { The bonding reaction between } \\
\text { the antifungal and AgNPs } \\
\text { might be chelation, which } \\
\text { altered the membrane } \\
\text { permeability and morphology. }\end{array}$ \\
\end{tabular}

tebuconazole, propineb, Bipolaria maydis fludioxonil
Antifungals and NPs were used individually and not complexed.
The synergism between antifungal

\begin{tabular}{ll}
\hline zineb & $\begin{array}{l}\text { Neoscytalidium } \\
\text { dimidiatum. }\end{array}$
\end{tabular}

Chitosan was used to functionalized with Ag-NPs and improve the NPs stability, then this compound was combined with zineb and meant to improve fungicidal effect.

\section{Antiviral}

\begin{tabular}{lll}
\hline $\mathrm{Ag}$ & oseltamivir (OTV) & $\begin{array}{l}\text { H1N1 influenza } \\
\text { virus. }\end{array}$
\end{tabular}

Ag-NPs and OTV were
synthesized together, being the
OTV on the surface of the Ag-NPs.

It is believed that Ag-NPs can facilitate OTV's entry into the cell to exert its antiviral action by reducing $\mathrm{ROS}$ and p53 levels.

\begin{tabular}{lll}
\hline $\mathrm{Ag}$ & FluPep & Influenza type-A \\
$\&$ & & virus. \\
$\mathrm{Au}$ & &
\end{tabular}

When alone, the MIC values were 2.5 and $5 \mathrm{mg} / \mathrm{mL}$ for $\mathrm{Ag}$-NPs and $\mathrm{AmB}$, respectively, whereas the MFC values were 10 and $>10 \mathrm{mg} / \mathrm{mL}$ for Ag-NPs and $\mathrm{AmB}$, respectively. However, when they were combined, the MIC and MFC values decreased to 0.156 and 2.5 $\mathrm{mg} / \mathrm{mL}$, respectively. compounds and Ag-NPs was measured by the percentage of inhibition towards B. maydis ranging from $46-58 \%$ for the Ag-NPs alone $48.28,47.27$ and $52.13 \%$ for the fungicides Tebuconazole, Propineb, Fludioxonil, respectively, and with values of $73.08,64.56$ and $62.13 \%$ for the combination of Ag-NPs with tebuconazole, propineb, fludioxonil, respectively, therefore proving a synergistic interaction between the NPs and the fungicides.
To prove the synergistic effects between $\mathrm{Ag}$-NPs and zineb, the inhibition zones were measured and were high when in combination.

\section{[118]}

For the infection growth in MDCK cells,

[127] the virus alone diminished cell viability to below $40 \%$, virus+OTV presented viability below $60 \%$ and the virus+Ag-NPs close to 70\%. Virus+Ag-NPs+OTV reached almost $100 \%$ of cell viability. Similar results were obtained for the mitochondrial membrane potential, proving the synergism between Ag-NPs and the antiviral OTV.

Ag-NPs and Au-NPs in combination with the peptide provide better antiviral activity than FluPep alone. FluPep alone had $\mathrm{IC}_{50}$ values ranging from $1-5 \mathrm{nM}$, whilst in combination with Au-NPs and $\mathrm{Ag}$-NPs, the value of $\mathrm{IC}_{50}$ decreased to $0.015 \mathrm{nM}$, proving a positive synergistic activity between the antiviral peptide and the NPs.

Although the majority of the research performed until now has focused on the synergistic interaction between Ag-NPs and antibiotics, other (fewer) experiments have 
been performed on other types of M-NPs conjugated with different drugs, such as antifungal or antiviral medicines, proving the versatility of M-NPs for a wide range of biomedical applications.

\section{Conclusions and Future Perspectives}

Metals are very interesting and promising vehicles to promote antimicrobial effects. Through this review, it is possible to access a compilation of several studies, showing that different metals can be used in different types of "structures" to achieve/increase biocidal behavior. For example, metal particles have been shown as efficient approaches to promote antimicrobial effects. Although they can be applied as micro- or nanostructures, the nano size is usually desirable to be applied in biomedical fields. Some works have reported that NPs, particularly Ag-NPs, can present good synergistic relations with antibiotics, resulting in an enhanced antibacterial effect on resistant strains of bacteria. Some authors have even proposed that this relation and the type of response could be transposed to studies with viruses, although there is a need for additional research in this field. Although several advantages regarding the use of M-NPs have been highlighted, there is still a need to improve many aspects, such as their production methodologies, which should be mostly achieved through biological synthesis methods, trying to use few chemicals, as well as generating lesser amounts of waste.

Regarding metallic surfaces and coatings, according to the examples presented here, $\mathrm{Cu}$ has proven to be the metal with the best biocidal properties against several microorganisms. In addition, anti-wetting properties were revealed to be important to improve the antimicrobial activity of metal surfaces or metal-coated surfaces. Overall, a variety of approaches for the development of these self-disinfecting surfaces were able to accomplish just that-create surfaces that kill pathogenic microorganisms, such as bacteria, viruses, and fungi upon direct contact. This is true even against the most recent threat to humanity, the SARS-CoV-2 (COVID-19) pandemic.

As for future projects, the study of dual functionality (involving the combination of biocidal agents with anti-adhesive surfaces) might be the key to the development of superefficient multifunctional and multimicrobial killing agents.

Author Contributions: Conceptualization, J.F.A.V. and Â.S.; writing-original draft preparation, D.P., T.S.C. and J.F.A.V.; writing-review and editing, and J.F.A.V., Â.S., N.A.; funding acquisition, J.F.A.V., N.A. and D.P. All authors have read and agreed to the published version of the manuscript.

Funding: This work was funded by the Fundação para a Ciência e a Tecnologia (FCT) and Centro2020 through the following Projects: UIDB/04044/2020, UIDP/04044/2020, UIDB/00709/2020, PAMIROTEIRO/0328/2013 (No. 22158), MATIS (CENTRO-01-0145-FEDER-000014) and Centro-01-02B7FEDER-069244. D. Pereira acknowledges her PhD fellowship (Ref. 2021.09331.BD).

Institutional Review Board Statement: Not applicable.

Informed Consent Statement: Not applicable.

Data Availability Statement: Not applicable.

Conflicts of Interest: The authors declare no conflict of interest.

\section{References}

1. Selvamani, V.; Zareei, A.; Elkashif, A.; Maruthamuthu, M.K.; Chittiboyina, S.; Delisi, D.; Li, Z.; Cai, L.; Pol, V.G.; Seleem, M.N.; et al. Hierarchical Micro/Mesoporous Copper Structure with Enhanced Antimicrobial Property via Laser Surface Texturing. Adv. Mater. Interfaces 2020, 7, 1901890. [CrossRef]

2. Raj, V.; Kim, Y.; Kim, Y.-G.; Lee, J.-H.; Lee, J. Chitosan-Gum Arabic Embedded Alizarin Nanocarriers Inhibit Biofilm Formation of Multispecies Microorganisms. Carbohydr. Polym. 2021, 2021, 118959. [CrossRef]

3. Ghosh, M.; Mandal, S.; Roy, A.; Chakrabarty, S.; Chakrabarti, G.; Pradhan, S.K. Enhanced antifungal activity of fluconazole conjugated with Cu-Ag-ZnO nanocomposite. Mater. Sci. Eng. C 2020, 106, 110160. [CrossRef] [PubMed]

4. Kefallinou, D.; Ellinas, K.; Speliotis, T.; Stamatakis, K.; Gogolides, E.; Tserepi, A. Optimization of Antibacterial Properties of "Hybrid" Metal-Sputtered Superhydrophobic Surfaces. Coatings 2019, 10, 25. [CrossRef] 
5. Smith, D.M.; Keller, A. DNA Nanostructures in the Fight Against Infectious Diseases. Adv. NanoBiomed Res. 2021, 1, 2000049. [CrossRef]

6. Zhang, L.; Lin, D.; Sun, X.; Curth, U.; Drosten, C.; Sauerhering, L.; Becker, S.; Rox, K.; Hilgenfeld, R. Crystal structure of SARS-CoV-2 main protease provides a basis for design of improved a-ketoamide inhibitors. Science 2020, 368, 409-412. [CrossRef]

7. Guindon, J.; Hohmann, A.G. Cannabinoid CB 2 receptors: A therapeutic target for the treatment of inflammatory and neuropathic pain. Br. J. Pharmacol. 2008, 153, 319-334. [CrossRef]

8. Raj, V.; Park, J.G.; Cho, K.H.; Choi, P.; Kim, T.; Ham, J.; Lee, J. Assessment of antiviral potencies of cannabinoids against SARS-CoV-2 using computational and in vitro approaches. Int. J. Biol. Macromol. 2021, 168, 474-485. [CrossRef]

9. Rai, M.; Deshmukh, S.D.; Ingle, A.P.; Gupta, I.R.; Galdiero, M.; Galdiero, S. Metal nanoparticles: The protective nanoshield against virus infection. Crit. Rev. Microbiol. 2016, 42, 46-56. [CrossRef]

10. Palza, H. Antimicrobial Polymers with Metal Nanoparticles. Int. J. Mol. Sci. 2015, 16, 2099-2116. [CrossRef]

11. Lemire, J.A.; Harrison, J.J.; Turner, R.J. Antimicrobial activity of metals: Mechanisms, molecular targets and applications. Nat. Rev. Microbiol. 2013, 11, 371-384. [CrossRef]

12. Sheldon, J.R.; Skaar, E.P. Metals as phagocyte antimicrobial effectors. Curr. Opin. Immunol. 2019, 60, 1-9. [CrossRef] [PubMed]

13. Abd-El-Aziz, A.S.; Agatemor, C.; Etkin, N. Antimicrobial resistance challenged with metal-based antimicrobial macromolecules. Biomaterials 2017, 118, 27-50. [CrossRef] [PubMed]

14. Devi, G.K.; Kumar, K.S.; Parthiban, R.; Kalishwaralal, K. An insight study on HPTLC fingerprinting of Mukia maderaspatna: Mechanism of bioactive constituents in metal nanoparticle synthesis and its activity against human pathogens. Microb. Pathog. 2017, 102, 120-132. [CrossRef] [PubMed]

15. Applications, T. Springer Handbook of Petroleum Technology; Hsu, C.S., Robinson, P.R., Eds.; Springer Handbooks; Springer International Publishing: Cham, Switzerland, 2017; ISBN 978-3-319-49345-9.

16. Akbarzadeh, A.; Kafshdooz, L.; Razban, Z.; Dastranj Tbrizi, A.; Rasoulpour, S.; Khalilov, R.; Kavetskyy, T.; Saghfi, S.; Nasibova, A.N.; Kaamyabi, S.; et al. An overview application of silver nanoparticles in inhibition of herpes simplex virus. Artif. Cells Nanomed. Biotechnol. 2018, 46, 263-267. [CrossRef]

17. Wang, L.; Hu, C.; Shao, L. The antimicrobial activity of nanoparticles: Present situation and prospects for the future. Int. J. Nanomed. 2017, 12, 1227-1249. [CrossRef]

18. Fernando, S.; Gunasekara, T.; Holton, J. Antimicrobial Nanoparticles: Applications and mechanisms of action. Sri Lankan J. Infect. Dis. 2018, 8, 2. [CrossRef]

19. Crane, J.K. Metal Nanoparticles in Infection and Immunity. Immunol. Investig. 2020, 49, 794-807. [CrossRef]

20. Khan, I.; Saeed, K.; Khan, I. Nanoparticles: Properties, applications and toxicities. Arab. J. Chem. 2019, 12, 908-931. [CrossRef]

21. Saravanan, A.; Kumar, P.S.; Karishma, S.; Vo, D.-V.N.; Jeevanantham, S.; Yaashikaa, P.R.; George, C.S. A review on biosynthesis of metal nanoparticles and its environmental applications. Chemosphere 2021, 264, 128580. [CrossRef]

22. Virji, M.A.; Stefaniak, A.B. A Review of Engineered Nanomaterial Manufacturing Processes and Associated Exposures; Elsevier: Amsterdam, The Netherlands, 2014; Volume 8, ISBN 9780080965338.

23. Neikov, O.D.; Naboychenko, S.S.; Murashova, I.B. Production of Noble Metal Powders, 2nd ed.; Elsevier Ltd.: Amsterdam, The Netherlands, 2019; ISBN 9780081005439.

24. Mensah, E.E.; Abbas, Z.; Azis, R.S.; Khamis, A.M. Enhancement of Complex Permittivity and Attenuation Properties of Recycled Hematite $\left(\alpha-\mathrm{Fe}_{2} \mathrm{O}_{3}\right)$ Using Nanoparticles Prepared via Ball Milling Technique. Materials 2019, 12, 1696. [CrossRef]

25. Karthik, S.; Suriyaprabha, R.; Balu, K.S.; Manivasakan, P.; Rajendran, V. Influence of ball milling on the particle size and antimicrobial properties of Tridax procumbens leaf nanoparticles. IET Nanobiotechnol. 2017, 11, 12-17. [CrossRef]

26. Alshora, D.H.; Ibrahim, M.A.; Alanazi, F.K. Nanotechnology from particle size reduction to enhancing aqueous solubility. In Surface Chemistry of Nanobiomaterials; Elsevier: Amsterdam, The Netherlands, 2016; pp. 163-191. ISBN 9780323428613.

27. Singh, J.; Sharma, S.; Soni, S.; Sharma, S.; Chand Singh, R. Influence of different milling media on structural, morphological and optical properties of the $\mathrm{ZnO}$ nanoparticles synthesized by ball milling process. Mater. Sci. Semicond. Process. 2019, 98, 29-38. [CrossRef]

28. Ayuk, E.L.; Ugwu, M.O.; Aronimo, S.B. A Review on Synthetic Methods of Nanostructured. Chem. Res. J. 2017, 2, 97-123.

29. Cheng, W.; Zhang, W.; Hu, L.; Ding, W.; Wu, F.; Li, J. Etching synthesis of iron oxide nanoparticles for adsorption of arsenic from water. RSC Adv. 2016, 6, 15900-15910. [CrossRef]

30. Verma, M.; Tyagi, I.; Chandra, R.; Gupta, V.K. Adsorptive removal of Pb (II) ions from aqueous solution using CuO nanoparticles synthesized by sputtering method. J. Mol. Liq. 2017, 225, 936-944. [CrossRef]

31. Strijckmans, K.; Schelfhout, R.; Depla, D. Tutorial: Hysteresis during the reactive magnetron sputtering process. J. Appl. Phys. 2018, 124, 241101. [CrossRef]

32. Fernández-Arias, M.; Boutinguiza, M.; del Val, J.; Riveiro, A.; Rodríguez, D.; Arias-González, F.; Gil, J.; Pou, J. Fabrication and Deposition of Copper and Copper Oxide Nanoparticles by Laser Ablation in Open Air. Nanomaterials 2020, 10, 300. [CrossRef] [PubMed]

33. Chung, W.-H.; Hwang, Y.-T.; Lee, S.-H.; Kim, H.-S. Electrical wire explosion process of copper/silver hybrid nano-particle ink and its sintering via flash white light to achieve high electrical conductivity. Nanotechnology 2016, 27, 205704. [CrossRef] [PubMed]

34. Hashemzadeh, A.; Ahmadi, R.; Yarali, D.; Sanaei, N. Synthesis of $\mathrm{MoO}_{2}$ nanoparticles via the electro-explosion of wire (EEW) method. Mater. Res. Express 2020, 6, 1250d3. [CrossRef] 
35. de Leon, A.; Advincula, R.C. Conducting Polymers with Superhydrophobic Effects as Anticorrosion Coating. In Intelligent Coatings for Corrosion Control; Elsevier: Amsterdam, The Netherlands, 2015; pp. 409-430. ISBN 9780124115347.

36. A C Sequeira, C. Electrochemical Synthesis of Iron Oxide Nanoparticles for Biomedical Application. Org. Med. Chem. Int. J. 2018, 5, 555660. [CrossRef]

37. Khaydarov, R.A.; Khaydarov, R.R.; Gapurova, O.; Estrin, Y.; Scheper, T. Electrochemical method for the synthesis of silver nanoparticles. J. Nanopart. Res. 2009, 11, 1193-1200. [CrossRef]

38. Anu Mary Ealia, S.; Saravanakumar, M.P. A review on the classification, characterisation, synthesis of nanoparticles and their application. IOP Conf. Ser. Mater. Sci. Eng. 2017, 263, 032019. [CrossRef]

39. Kumar, R.; Nayak, M.; Sahoo, G.C.; Pandey, K.; Sarkar, M.C.; Ansari, Y.; Das, V.N.R.; Topno, R.K.; Madhukar, M.; Das, P. Iron oxide nanoparticles based antiviral activity of H1N1 influenza A virus. J. Infect. Chemother. 2019, 25, 325-329. [CrossRef]

40. Bankier, C.; Matharu, R.K.; Cheong, Y.K.; Ren, G.G.; Cloutman-Green, E.; Ciric, L. Synergistic Antibacterial Effects of Metallic Nanoparticle Combinations. Sci. Rep. 2019, 9, 16074. [CrossRef]

41. Singh, L.; Kruger, H.G.; Maguire, G.E.M.; Govender, T.; Parboosing, R. The role of nanotechnology in the treatment of viral infections. Ther. Adv. Infect. Dis. 2017, 4, 105-131. [CrossRef]

42. Carvalho, A.P.A.; Conte-Junior, C.A. Recent Advances on Nanomaterials to COVID-19 Management: A Systematic Review on Antiviral/Virucidal Agents and Mechanisms of SARS-CoV-2 Inhibition/Inactivation. Glob. Chall. 2021, 5, 2000115. [CrossRef]

43. Khurana, C.; Sharma, P.; Pandey, O.P.; Chudasama, B. Synergistic Effect of Metal Nanoparticles on the Antimicrobial Activities of Antibiotics against Biorecycling Microbes. J. Mater. Sci. Technol. 2016, 32, 524-532. [CrossRef]

44. Nguyen, N.-Y.T.; Grelling, N.; Wetteland, C.L.; Rosario, R.; Liu, H. Antimicrobial Activities and Mechanisms of Magnesium Oxide Nanoparticles (nMgO) against Pathogenic Bacteria, Yeasts, and Biofilms. Sci. Rep. 2018, 8, 16260. [CrossRef]

45. Shankar, S.; Rhim, J.-W. Amino acid mediated synthesis of silver nanoparticles and preparation of antimicrobial agar/silver nanoparticles composite films. Carbohydr. Polym. 2015, 130, 353-363. [CrossRef]

46. Chatterjee, T.; Chatterjee, B.K.; Majumdar, D.; Chakrabarti, P. Antibacterial effect of silver nanoparticles and the modeling of bacterial growth kinetics using a modified Gompertz model. Biochim. Biophys. Acta—Gen. Subj. 2015, 1850, 299-306. [CrossRef] [PubMed]

47. Ismail, A.O.; Ajayi, S.O.; Alausa, A.O.; Ogundile, O.P.; Ademosun, O.T. Antimicrobial and antibiofilm activities of green synthesized silver nanoparticles for water treatment. J. Phys. Conf. Ser. 2021, 1734, 012043. [CrossRef]

48. de Toledo, L.d.A.S.; Rosseto, H.C.; Bruschi, M.L. Iron oxide magnetic nanoparticles as antimicrobials for therapeutics. Pharm. Dev. Technol. 2018, 23, 316-323. [CrossRef]

49. Xu, C.; Akakuru, O.U.; Zheng, J.; Wu, A. Applications of iron oxide-based magnetic nanoparticles in the diagnosis and treatment of bacterial infections. Front. Bioeng. Biotechnol. 2019, 7, 141. [CrossRef] [PubMed]

50. Kim, M.-H.; Yamayoshi, I.; Mathew, S.; Lin, H.; Nayfach, J.; Simon, S.I. Magnetic nanoparticle targeted hyperthermia of cutaneous Staphylococcus aureus infection. Ann. Biomed. Eng. 2013, 41, 598-609. [CrossRef]

51. Kumari, M.; Giri, V.P.; Pandey, S.; Kumar, M.; Katiyar, R.; Nautiyal, C.S.; Mishra, A. An insight into the mechanism of antifungal activity of biogenic nanoparticles than their chemical counterparts. Pestic. Biochem. Physiol. 2019, 157, 45-52. [CrossRef]

52. Li, J.; Sang, H.; Guo, H.; Popko, J.T.; He, L.; White, J.C.; Parkash Dhankher, O.; Jung, G.; Xing, B. Antifungal mechanisms of ZnO and Ag nanoparticles to Sclerotinia homoeocarpa. Nanotechnology 2017, 28, 155101. [CrossRef]

53. Zhang, F.; Liu, X.; Pentok, M.; Sauli, E.; He, N.; Zen, X.; Li, X.; Liu, T. Molecular Mechanism and Changes of Antioxidant Enzyme in ZnO Nanoparticles Against Fungus. J. Biomed. Nanotechnol. 2019, 15, 647-661. [CrossRef]

54. Mahdavi, B.; Saneei, S.; Qorbani, M.; Zhaleh, M.; Zangeneh, A.; Zangeneh, M.M.; Pirabbasi, E.; Abbasi, N.; Ghaneialvar, H. Ziziphora clinopodioides Lam leaves aqueous extract mediated synthesis of zinc nanoparticles and their antibacterial, antifungal, cytotoxicity, antioxidant, and cutaneous wound healing properties under in vitro and in vivo conditions. Appl. Organomet. Chem. 2019, 33, e5164. [CrossRef]

55. Punjabi, K.; Mehta, S.; Chavan, R.; Chitalia, V.; Deogharkar, D.; Deshpande, S. Efficiency of Biosynthesized Silver and Zinc Nanoparticles Against Multi-Drug Resistant Pathogens. Front. Microbiol. 2018, 9, 2207. [CrossRef]

56. Attia, G.H.; Moemen, Y.S.; Youns, M.; Ibrahim, A.M.; Abdou, R.; El Raey, M.A. Antiviral zinc oxide nanoparticles mediated by hesperidin and in silico comparison study between antiviral phenolics as anti-SARS-CoV-2. Colloids Surf. B Biointerfaces 2021, 203, 111724. [CrossRef] [PubMed]

57. Miri, A.; Mahdinejad, N.; Ebrahimy, O.; Khatami, M.; Sarani, M. Zinc oxide nanoparticles: Biosynthesis, characterization, antifungal and cytotoxic activity. Mater. Sci. Eng. C 2019, 104, 109981. [CrossRef]

58. Ghaffari, H.; Tavakoli, A.; Moradi, A.; Tabarraei, A.; Bokharaei-Salim, F.; Zahmatkeshan, M.; Farahmand, M.; Javanmard, D.; Kiani, S.J.; Esghaei, M.; et al. Inhibition of H1N1 influenza virus infection by zinc oxide nanoparticles: Another emerging application of nanomedicine. J. Biomed. Sci. 2019, 26, 70. [CrossRef]

59. Sedaghat Anbouhi, T.; Mokhtari Esfidvajani, E.; Nemati, F.; Haghighat, S.; Sari, S.; Attar, F.; Pakaghideh, A.; Sohrabi, M.J.; Mousavi, S.E.; Falahati, M. Albumin binding, anticancer and antibacterial properties of synthesized zero valent iron nanoparticles. Int. J. Nanomed. 2018, 14, 243-256. [CrossRef]

60. Choudhary, S.; Kumar, R.; Dalal, U.; Tomar, S.; Reddy, S.N. Green synthesis of nanometal impregnated biomass-Antiviral potential. Mater. Sci. Eng. C 2020, 112, 110934. [CrossRef] [PubMed] 
61. Win, T.T.; Khan, S.; Bo, B.; Zada, S.; Fu, P.C. Green synthesis and characterization of $\mathrm{Fe}_{3} \mathrm{O}_{4}$ nanoparticles using Chlorella-K01 extract for potential enhancement of plant growth stimulating and antifungal activity. Sci. Rep. 2021, 11, 1-11. [CrossRef]

62. Parveen, S.; Wani, A.H.; Shah, M.A.; Devi, H.S.; Bhat, M.Y.; Koka, J.A. Preparation, characterization and antifungal activity of iron oxide nanoparticles. Microb. Pathog. 2018, 115, 287-292. [CrossRef]

63. Seydi, N.; Mahdavi, B.; Paydarfard, S.; Zangeneh, A.; Zangeneh, M.M.; Najafi, F.; Jalalvand, A.R.; Pirabbasi, E. Preparation, characterization, and assessment of cytotoxicity, antioxidant, antibacterial, antifungal, and cutaneous wound healing properties of titanium nanoparticles using aqueous extract of Ziziphora clinopodioides Lam leaves. Appl. Organomet. Chem. 2019, 33 , e5009. [CrossRef]

64. Arya, S.; Sonawane, H.; Math, S.; Tambade, P.; Chaskar, M.; Shinde, D. Biogenic titanium nanoparticles (TiO ${ }_{2} \mathrm{NPs}_{\text {) from Tricoderma }}$ citrinoviride extract: Synthesis, characterization and antibacterial activity against extremely drug-resistant Pseudomonas aeruginosa. Int. Nano Lett. 2021, 11, 35-42. [CrossRef]

65. Noori, A.J.; Kareem, F.A. The effect of magnesium oxide nanoparticles on the antibacterial and antibiofilm properties of glassionomer cement. Heliyon 2019, 5, e02568. [CrossRef] [PubMed]

66. Pugazhendhi, A.; Prabhu, R.; Muruganantham, K.; Shanmuganathan, R.; Natarajan, S. Anticancer, antimicrobial and photocatalytic activities of green synthesized magnesium oxide nanoparticles (MgONPs) using aqueous extract of Sargassum wightii. J. Photochem. Photobiol. B Biol. 2019, 190, 86-97. [CrossRef]

67. Rafiei, S.; Rezatofighi, S.E.; Ardakani, M.R.; Madadgar, O. In vitro anti-foot-and-mouth disease virus activity of magnesium oxide nanoparticles. IET Nanobiotechnol. 2015, 9, 247-251. [CrossRef]

68. Hassanien, R.; Husein, D.Z.; Al-Hakkani, M.F. Biosynthesis of copper nanoparticles using aqueous Tilia extract: Antimicrobial and anticancer activities. Heliyon 2018, 4, e01077. [CrossRef] [PubMed]

69. Kiriyanthan, R.M.; Sharmili, S.A.; Balaji, R.; Jayashree, S.; Mahboob, S.; Al-Ghanim, K.A.; Al-Misned, F.; Ahmed, Z.; Govindarajan, M.; Vaseeharan, B. Photocatalytic, antiproliferative and antimicrobial properties of copper nanoparticles synthesized using Manilkara zapota leaf extract: A photodynamic approach. Photo Diagn. Photodyn. Ther. 2020, 32, 102058. [CrossRef] [PubMed]

70. Amiri, M.; Etemadifar, Z.; Daneshkazemi, A.; Nateghi, M. Antimicrobial Effect of Copper Oxide Nanoparticles on Some Oral Bacteria and Candida Species. J. Dent. Biomater. 2017, 4, 347-352.

71. Tavakoli, A.; Hashemzadeh, M.S. Inhibition of herpes simplex virus type 1 by copper oxide nanoparticles. J. Virol. Methods 2020, 275, 113688. [CrossRef]

72. Bezza, F.A.; Tichapondwa, S.M.; Chirwa, E.M.N. Fabrication of monodispersed copper oxide nanoparticles with potential application as antimicrobial agents. Sci. Rep. 2020, 10, 16680. [CrossRef]

73. Donga, S.; Bhadu, G.R.; Chanda, S. Antimicrobial, antioxidant and anticancer activities of gold nanoparticles green synthesized using Mangifera indica seed aqueous extract. Artif. Cells Nanomed. Biotechnol. 2020, 48, 1315-1325. [CrossRef] [PubMed]

74. Vijayan, R.; Joseph, S.; Mathew, B. Eco-friendly synthesis of silver and gold nanoparticles with enhanced antimicrobial, antioxidant, and catalytic activities. IET Nanobiotechnol. 2018, 12, 850-856. [CrossRef]

75. Kim, J.; Yeom, M.; Lee, T.; Kim, H.-O.; Na, W.; Kang, A.; Lim, J.-W.; Park, G.; Park, C.; Song, D.; et al. Porous gold nanoparticles for attenuating infectivity of influenza A virus. J. Nanobiotechnol. 2020, 18, 54. [CrossRef]

76. Halder, A.; Das, S.; Ojha, D.; Chattopadhyay, D.; Mukherjee, A. Highly monodispersed gold nanoparticles synthesis and inhibition of herpes simplex virus infections. Mater. Sci. Eng. C 2018, 89, 413-421. [CrossRef] [PubMed]

77. Soto, K.M.; Quezada-Cervantes, C.T.; Hernández-Iturriaga, M.; Luna-Bárcenas, G.; Vazquez-Duhalt, R.; Mendoza, S. Fruit peels waste for the green synthesis of silver nanoparticles with antimicrobial activity against foodborne pathogens. LWT 2019, 103, 293-300. [CrossRef]

78. Valsalam, S.; Agastian, P.; Arasu, M.V.; Al-Dhabi, N.A.; Ghilan, A.-K.M.; Kaviyarasu, K.; Ravindran, B.; Chang, S.W.; Arokiyaraj, S. Rapid biosynthesis and characterization of silver nanoparticles from the leaf extract of Tropaeolum majus L. and its enhanced in-vitro antibacterial, antifungal, antioxidant and anticancer properties. J. Photochem. Photobiol. B Biol. 2019, 191, 65-74. [CrossRef]

79. Jebril, S.; Khanfir Ben Jenana, R.; Dridi, C. Green synthesis of silver nanoparticles using Melia azedarach leaf extract and their antifungal activities: In vitro and in vivo. Mater. Chem. Phys. 2020, 248, 122898. [CrossRef]

80. Szymańska, E.; Orłowski, P.; Winnicka, K.; Tomaszewska, E.; Bąska, P.; Celichowski, G.; Grobelny, J.; Basa, A.; Krzyżowska, M. Multifunctional Tannic Acid/Silver Nanoparticle-Based Mucoadhesive Hydrogel for Improved Local Treatment of HSV Infection: In Vitro and In Vivo Studies. Int. J. Mol. Sci. 2018, 19, 387. [CrossRef]

81. Haggag, E.; Elshamy, A.; Rabeh, M.; Gabr, N.; Salem, M.; Youssif, K.; Samir, A.; Bin Muhsinah, A.; Alsayari, A.; Abdelmohsen, U.R. Antiviral potential of green synthesized silver nanoparticles of Lampranthus coccineus and Malephora lutea. Int. J. Nanomed. 2019, 14, 6217-6229. [CrossRef]

82. Jeremiah, S.S.; Miyakawa, K.; Morita, T.; Yamaoka, Y.; Ryo, A. Potent antiviral effect of silver nanoparticles on SARS-CoV-2. Biochem. Biophys. Res. Commun. 2020, 533, 195-200. [CrossRef] [PubMed]

83. Morris, D.; Ansar, M.; Speshock, J.; Ivanciuc, T.; Qu, Y.; Casola, A.; Garofalo, R. Antiviral and Immunomodulatory Activity of Silver Nanoparticles in Experimental RSV Infection. Viruses 2019, 11, 732. [CrossRef] [PubMed]

84. Lara, H.H.; Ayala-Nuñez, N.V.; Ixtepan-Turrent, L.; Rodriguez-Padilla, C. Mode of antiviral action of silver nanoparticles against HIV-1. J. Nanobiotechnol. 2010, 8, 1. [CrossRef] [PubMed]

85. Sreekanth, T.V.M.; Pandurangan, M.; Kim, D.H.; Lee, Y.R. Green Synthesis: In-vitro Anticancer Activity of Silver Nanoparticles on Human Cervical Cancer Cells. J. Clust. Sci. 2016, 27, 671-681. [CrossRef] 
86. Aderibigbe, B. Metal-Based Nanoparticles for the Treatment of Infectious Diseases. Molecules 2017, 22, 1370. [CrossRef]

87. Maduray, K.; Parboosing, R. Metal Nanoparticles: A Promising Treatment for Viral and Arboviral Infections. Biol. Trace Elem. Res. 2020, 2020, 1-18. [CrossRef]

88. Gurunathan, S.; Qasim, M.; Choi, Y.; Do, J.T.; Park, C.; Hong, K.; Kim, J.-H.; Song, H. Antiviral Potential of Nanoparticles-Can Nanoparticles Fight Against Coronaviruses? Nanomaterials 2020, 10, 1645. [CrossRef] [PubMed]

89. Stack, M.; Parikh, D.; Wang, H.; Wang, L.; Xu, M.; Zou, J.; Cheng, J.; Wang, H. Electrospun Nanofibers for Drug Delivery. In Electrospinning: Nanofabrication and Applications; Elsevier: Amsterdam, The Netherlands, 2019; pp. 735-764. ISBN 9780323512701.

90. Willerth, S. Drug delivery systems for engineering neural tissue. In Engineering Neural Tissue from Stem Cells; Elsevier: Amsterdam, The Netherlands, 2017; pp. 159-180. ISBN 9780128113851.

91. Jin, S.-E.; Jin, H.-E. Antimicrobial Activity of Zinc Oxide Nano/Microparticles and Their Combinations against Pathogenic Microorganisms for Biomedical Applications: From Physicochemical Characteristics to Pharmacological Aspects. Nanomaterials 2021, 11, 263. [CrossRef]

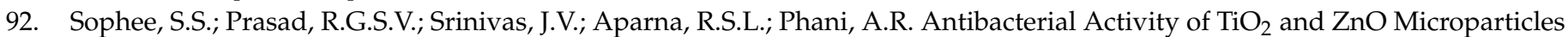
Combination on Water Polluting Bacteria. J. Green Sci. Technol. 2013, 1, 20-26. [CrossRef]

93. Steckiewicz, K.P.; Zwara, J.; Jaskiewicz, M.; Kowalski, S.; Kamysz, W.; Zaleska-Medynska, A.; Inkielewicz-Stepniak, I. ShapeDepended Biological Properties of $\mathrm{Ag}_{3} \mathrm{PO}_{4}$ Microparticles: Evaluation of Antimicrobial Properties and Cytotoxicity in In Vitro Model-Safety Assessment of Potential Clinical Usage. Oxid. Med. Cell. Longev. 2019, 2019, 6740325. [CrossRef] [PubMed]

94. Sunada, K.; Minoshima, M.; Hashimoto, K. Highly efficient antiviral and antibacterial activities of solid-state cuprous compounds. J. Hazard. Mater. 2012, 235-236, 265-270. [CrossRef] [PubMed]

95. Ellinas, K.; Kefallinou, D.; Stamatakis, K.; Gogolides, E.; Tserepi, A. Is There a Threshold in the Antibacterial Action of Superhydrophobic Surfaces? ACS Appl. Mater. Interfaces 2017, 9, 39781-39789. [CrossRef]

96. Ballo, M.K.S.; Rtimi, S.; Kiwi, J.; Pulgarin, C.; Entenza, J.M.; Bizzini, A. Fungicidal activity of copper-sputtered flexible surfaces under dark and actinic light against azole-resistant Candida albicans and Candida glabrata. J. Photochem. Photobiol. B Biol. 2017, 174, 229-234. [CrossRef] [PubMed]

97. Akhidime, I.D.; Saubade, F.; Benson, P.S.; Butler, J.A.; Olivier, S.; Kelly, P.; Verran, J.; Whitehead, K.A. The antimicrobial effect of metal substrates on food pathogens. Food Bioprod. Process. 2019, 113, 68-76. [CrossRef]

98. Minoshima, M.; Lu, Y.; Kimura, T.; Nakano, R.; Ishiguro, H.; Kubota, Y.; Hashimoto, K.; Sunada, K. Comparison of the antiviral effect of solid-state copper and silver compounds. J. Hazard. Mater. 2016, 312, 1-7. [CrossRef]

99. Noyce, J.O.; Michels, H.; Keevil, C.W. Inactivation of Influenza A Virus on Copper versus Stainless Steel Surfaces. Appl. Environ. Microbiol. 2007, 73, 2748-2750. [CrossRef]

100. Warnes, S.L.; Little, Z.R.; Keevil, C.W. Human Coronavirus 229E Remains Infectious on Common Touch Surface Materials. MBio 2015, 6, e01697-15. [CrossRef]

101. Wilks, S.A.; Michels, H.; Keevil, C.W. The survival of Escherichia coli O157 on a range of metal surfaces. Int. J. Food Microbiol. 2005, 105, 445-454. [CrossRef]

102. Hutasoit, N.; Kennedy, B.; Hamilton, S.; Luttick, A.; Rahman Rashid, R.A.; Palanisamy, S. SARS-CoV-2 (COVID-19) inactivation capability of copper-coated touch surface fabricated by cold-spray technology. Manuf. Lett. 2020, 25, 93-97. [CrossRef]

103. Bastos, R.W.; Rossato, L.; Valero, C.; Lagrou, K.; Colombo, A.L.; Goldman, G.H. Potential of Gallium as an Antifungal Agent. Front. Cell. Infect. Microbiol. 2019, 9, 414. [CrossRef]

104. Yuan, Y.; Hays, M.P.; Hardwidge, P.R.; Kim, J. Surface characteristics influencing bacterial adhesion to polymeric substrates. RSC Adv. 2017, 7, 14254-14261. [CrossRef]

105. Kao, H.; Chen, C.-C.; Huang, Y.-R.; Chu, Y.-H.; Csík, A.; Ding, S.-J. Metal ion-dependent tailored antibacterial activity and biological properties of polydopamine-coated titanium implants. Surf. Coat. Technol. 2019, 378, 124998. [CrossRef]

106. Vazquez-Muñoz, R.; Meza-Villezcas, A.; Fournier, P.G.J.; Soria-Castro, E.; Juarez-Moreno, K.; Gallego-Hernández, A.L.; Bogdanchikova, N.; Vazquez-Duhalt, R.; Huerta-Saquero, A. Enhancement of antibiotics antimicrobial activity due to the silver nanoparticles impact on the cell membrane. PLoS ONE 2019, 14, e0224904. [CrossRef] [PubMed]

107. Ghandali, N.; Masumeh, S.; Safarkar, R. A review of applications and mechanisms nanoparticles on inhibiting the growth of pathogens. Asian J. Nanosci. Mater. 2021, 4, 67-80. [CrossRef]

108. Gatadi, S.; Madhavi, Y.V.; Nanduri, S. Nanoparticle drug conjugates treating microbial and viral infections: A review. J. Mol. Struct. 2021, 1228, 129750. [CrossRef]

109. Salleh, A.; Naomi, R.; Utami, N.D.; Mohammad, A.W.; Mahmoudi, E.; Mustafa, N.; Fauzi, M.B. The potential of silver nanoparticles for antiviral and antibacterial applications: A mechanism of action. Nanomaterials 2020, 10, 1566. [CrossRef]

110. Shaikh, S.; Nazam, N.; Rizvi, S.M.D.; Ahmad, K.; Baig, M.H.; Lee, E.J.; Choi, I. Mechanistic insights into the antimicrobial actions of metallic nanoparticles and their implications for multidrug resistance. Int. J. Mol. Sci. 2019, 20, 2468. [CrossRef]

111. Deshmukh, S.P.; Patil, S.M.; Mullani, S.B.; Delekar, S.D. Silver nanoparticles as an effective disinfectant: A review. Mater. Sci. Eng. C 2019, 97, 954-965. [CrossRef]

112. McShan, D.; Zhang, Y.; Deng, H.; Ray, P.C.; Yu, H. Synergistic Antibacterial Effect of Silver Nanoparticles Combined with Ineffective Antibiotics on Drug Resistant Salmonella typhimurium DT104. J. Environ. Sci. Health Part C 2015, 33, 369-384. [CrossRef] [PubMed] 
113. Wypij, M.; Golinska, P.; Dahm, H.; Rai, M. Actinobacterial-mediated synthesis of silver nanoparticles and their activity against pathogenic bacteria. IET Nanobiotechnol. 2017, 11, 336-342. [CrossRef] [PubMed]

114. Abo-Shama, U.H.; El-Gendy, H.; Mousa, W.S.; Hamouda, R.A.; Yousuf, W.E.; Hetta, H.F.; Abdeen, E.E. Synergistic and antagonistic effects of metal nanoparticles in combination with antibiotics against some reference strains of pathogenic microorganisms. Infect. Drug Resist. 2020, 13, 351-362. [CrossRef]

115. Pereira, A.K.d.S.; Reis, D.T.; Barbosa, K.M.; Scheidt, G.N.; da Costa, L.S.; Santos, L.S.S. Antibacterial effects and ibuprofen release potential using chitosan microspheres loaded with silver nanoparticles. Carbohydr. Res. 2020, 488, 107891. [CrossRef]

116. Jyoti, K.; Baunthiyal, M.; Singh, A. Characterization of silver nanoparticles synthesized using Urtica dioica Linn. leaves and their synergistic effects with antibiotics. J. Radiat. Res. Appl. Sci. 2016, 9, 217-227. [CrossRef]

117. Baker, S.; Pasha, A.; Satish, S. Biogenic nanoparticles bearing antibacterial activity and their synergistic effect with broad spectrum antibiotics: Emerging strategy to combat drug resistant pathogens. Saudi Pharm. J. 2017, 25, 44-51. [CrossRef]

118. Moteriya, P.; Chanda, S. Biosynthesis of silver nanoparticles formation from Caesalpinia pulcherrima stem metabolites and their broad spectrum biological activities. J. Genet. Eng. Biotechnol. 2018, 16, 105-113. [CrossRef] [PubMed]

119. Lee, B.; Lee, D.G. Synergistic antibacterial activity of gold nanoparticles caused by apoptosis-like death. J. Appl. Microbiol. 2019, 127, 701-712. [CrossRef] [PubMed]

120. Sportelli, M.C.; Longano, D.; Bonerba, E.; Tantillo, G.; Torsi, L.; Sabbatini, L.; Cioffi, N.; Ditaranto, N. Electrochemical preparation of synergistic nanoantimicrobials. Molecules 2020, 25, 49. [CrossRef] [PubMed]

121. Mandava, K.; Kadimcharla, K.; Keesara, N.R.; Fatima, S.N.; Bommena, P.; Batchu, U.R. Green Synthesis of Stable Copper Nanoparticles and Synergistic Activity with Antibiotics. Indian J. Pharm. Sci. 2017, 79, 695-700. [CrossRef]

122. Nejabatdoust, A.; Salehzadeh, A.; Zamani, H.; Moradi-Shoeili, Z. Synthesis, Characterization and Functionalization of ZnO Nanoparticles by Glutamic Acid (Glu) and Conjugation of ZnO@Glu by Thiosemicarbazide and Its Synergistic Activity with Ciprofloxacin Against Multi-drug Resistant Staphylococcus aureus. J. Clust. Sci. 2019, 30, 329-336. [CrossRef]

123. Ghasemi, N.; Seyfi, J.; Asadollahzadeh, M.J. Imparting superhydrophobic and antibacterial properties onto the cotton fabrics: Synergistic effect of zinc oxide nanoparticles and octadecanethiol. Cellulose 2018, 25, 4211-4222. [CrossRef]

124. Jin, T.; He, Y. Antibacterial activities of magnesium oxide (MgO) nanoparticles against foodborne pathogens. J. Nanopart. Res. 2011, 13, 6877-6885. [CrossRef]

125. Huang, W.; Wang, C.; Duan, H.M.; Bi, Y.L.; Wu, D.; Du, J.L.; Yu, H. Synergistic antifungal effect of biosynthesized silver nanoparticles combined with fungicides. Int. J. Agric. Biol. 2018, 20, 1225-1229. [CrossRef]

126. Ngoc, U.T.P.; Nguyen, D.H. Synergistic antifungal effect of fungicide and chitosan-silver nanoparticles on Neoscytalidium dimidiatum. Green Process. Synth. 2018, 7, 132-138. [CrossRef]

127. Li, Y.; Lin, Z.; Zhao, M.; Xu, T.; Wang, C.; Hua, L.; Wang, H.; Xia, H.; Zhu, B. Silver Nanoparticle Based Codelivery of Oseltamivir to Inhibit the Activity of the H1N1 Influenza Virus through ROS-Mediated Signaling Pathways. ACS Appl. Mater. Interfaces 2016, 8, 24385-24393. [CrossRef] [PubMed]

128. Alghrair, Z.K.; Fernig, D.G.; Ebrahimi, B. Enhanced inhibition of influenza virus infection by peptide-noble-metal nanoparticle conjugates. Beilstein J. Nanotechnol. 2019, 10, 1038-1047. [CrossRef] [PubMed] 